\begin{abstract}
UNIVERSIDADE DE SÃO PAULO
FACULDADE DE FILOSOFIA, LETRAS E CIÊNCIAS HUMANAS DEPARTAMENTO DE LETRAS MODERNAS

PROGRAMA DE PÓS-GRADUAÇÃO EM LÍNGUA ESPANHOLA E LITERATURAS ESPANHOLA E HISPANO-AMERICANA
\end{abstract}

FABIO LUCIANO

A REPRESENTAÇÃO DO “DISCRETO”:

A FILHA DO COMENDADOR EM EL BURLADOR DE SEVILLA

São Paulo

2011 


\author{
UNIVERSIDADE DE SÃO PAULO \\ FACULDADE DE FILOSOFIA, LETRAS E CIÊNCIAS HUMANAS
}

FABIO LUCIANO

\title{
A REPRESENTAÇÃO DO “DISCRETO”: A FILHA DO COMENDADOR EM EL BURLADOR DE SEVILLA
}

O texto deste exemplar incorpora a revisão feita no original.

De acordo,

Profa. Dra. María de la Concepción Piñero Valverde

Dissertação apresentada ao

Programa de Pós-Graduação em

Língua Espanhola e Literaturas

Espanhola e Hispano-americana, do

Departamento de Letras Modernas da Faculdade de Filosofia, Letras e Ciências Humanas da Universidade de São Paulo, para obtenção do título de Mestre em Letras.

Orientada pela Profa. Dra. María de la Concepción Piñero Valverde

São Paulo 
Autorizo a reprodução e divulgação total ou parcial deste trabalho, por qualquer meio convencional ou eletrônico, para fins de estudo e pesquisa, desde que citada a fonte.

Catalogação na Publicação

Serviço de Biblioteca e Documentação

Faculdade de Filosofia, Letras e Ciências Humanas da Universidade de São Paulo

Luciano, Fabio

A representação do discreto : a filha do Comendador em El burlador de Sevilla / Fabio Luciano; orientadora Maria de la Concepción Piñero Valverde. - São Paulo, 2011.

$92 \mathrm{f}$.

Dissertação (Mestrado) - Faculdade de Filosofia, Letras e Ciências Humanas da Universidade de São Paulo. Departamento de Letras Modernas. Área de concentração: Língua Espanhola e Literatura Espanhola e Hispano-americana.

1. Literatura espanhola. 2. Condição feminina. I.

Título. 3. Teatro - Espanha. 4. El burlador de Sevilla. II. Piñero Valverde, Maria de La Concepción. 


\section{DEDICATÓRIA}

Dedico este trabalho:

a Deus. Principal motivo que me levou a superar obstáculos e a vencer desafios com ânimo, humildade e dedicação;

a meu irmão Rafael pelo respeito, apoio e cumplicidade nos momentos mais oportunos;

e especialmente aos meus pais, Mário e Tânia, pela infinita paciência e uma educação exemplar sempre alicerçada no respeito recíproco. 


\section{AGRADECIMENTOS}

À Professora Doutora María de la Concepción Piñero Valverde, pela democrática e paciente orientação. Inclusive, tanto pela objetividade nas ações quanto pelo rigor acadêmico de seus apontamentos, mostrando-me que sou capaz de realizar grandes feitos.

À Professora Doutora Sandra Regina Keppler, que teve decisiva participação no desenvolvimento deste trabalho.

À Professora Doutora Maria Augusta da Costa Viera, pelas sugestões imprescindíveis e bem claras sobre minha pesquisa.

À Professora Doutora Valéria de Marco pelas aulas e pelo fraterno incentivo desde as primeiras reflexões.

À Professora Doutora Fátima Aparecida Teves Cabral Bruno pelo apoio e na confiança depositada em nossas atividades referentes ao grupo de pesquisa. Também pelo ânimo propiciado em diferentes momentos.

À Professora Doutora Lílian Jacoto, pela simpatia ao esclarecer dúvidas e na prontidão de suas respostas.

Aos amigos: Ana Paula Silva, Andrea Augusta Aguiar, Carolina Regina Morales, Caroline Arantes Magalhães Castilhone, Cristiane Prando Martini, Eliane Aparecida Sabatine, Érico Gleria, Gustavo Rodrigues da Silva, Isabella Moraes Gallardo, Márcia Romero Marçal, Mateus Moisés Pereira, Ricardo dos Santos Inamine e Renato Jorge Felismino.

Às Irmãs Passionistas e às Irmãs Consolata, pelo conforto nas horas necessárias e pelo incentivo.

$E$, claro, não poderia deixar de mencionar a participação de meus alunos (Colégio Passionista São Paulo da Cruz, Colégio Consolata e Español en el Campus). Eles contribuíram para a viabilidade de meu trabalho e souberam brilhantemente - "dar vida" às personagens das obras El Burlador de Sevilla e Don Juan Tenorio. 


\section{EPÍGRAFE}

A vida como realidade é presença absoluta: não se pode dizer que "existe" algo se não é presente ou atual. Se existe passado, ele existe como presente e atuando sobre nós. Com efeito, se analisamos o que somos agora, se examinamos a consistência de nosso presente, decompondo-o em seus elementos, como faz o químico ou o físico com um corpo, percebemos logo que nossa vida, que é sempre esta, a deste instante presente ou atual, compõe-se do que temos sido pessoal e coletivamente. 


\section{RESUMO}

LUCIANO, F. A Representação do "Discreto": a Filha do Comendador em 'El Burlador de Sevilla'. 2011. 92 f. Dissertação (Mestrado) - Faculdade de Filosofia, Letras e Ciências Humanas, Universidade de São Paulo, São Paulo, 2011.

Tomando como referenciais teóricos e críticos autores como Aristóteles, Lope de Vega, Porqueras Mayo, Jaime Cortesão e João Adolfo Hansen e levando em conta os principais aspectos culturais da sociedade espanhola do século XVII, este trabalho tem seu foco de interesse na personagem Dona Ana de Ulloa, Filha do Comendador em El Burlador de Sevilla, que é arrebatada por Dom Juan. Buscou-se entender como o modo de ser "discreto" se articulava na corte espanhola da época, tentando esclarecer as motivações dessa atitude nas ações da Filha, pois será através dessa poética da moralidade que ocorrerá, ao final da ação dramática, o restabelecimento da ordem social. Para a compreensão da atitude da protagonista, procedeu-se a uma discussão, tanto no âmbito moral quanto no literário, do conceito e das conotações do termo "discreto" na época. A dissertação se divide em três partes. A primeira focaliza aspectos sociais, culturais e históricos da sociedade espanhola do século XVII presentes em El Burlador de Sevilla, atentando para a atitude discreta como um elemento que diferencia Dona Ana das outras personagens femininas da peça. A segunda procura destacar a Filha do Comendador, interpretando-a pela atitude incisiva e mostrando como ela se choca com o perfil de mulher predominante na época, ou seja, aquela que em geral era tratada pelos homens como objeto e apreciada por sua beleza, sua nobreza e seu "preparo" para o casamento. Já a terceira parte centra-se no relacionamento entre Dona Ana e as personagens masculinas, no que ressalta a questão da representação do "querer" e do "poder", provocando o desencadeamento de uma dupla justiça: a terrena, posta nas mãos do Rei e reafirmada pela atuação do Comendador, e a divina, que acaba por sugerir um ideal de liberdade católico, personificado no Convidado de Pedra. Assim, a protagonista se debaterá entre preceitos relacionados ora a uma justiça dos homens, ora a uma justiça de Deus. As considerações finais amarram essas análises, concluindo pela universalidade da personagem feminina representada por Dona Ana, que é recriada em autores de diversas tradições culturais, bem como de épocas distintas.

Palavras-Chave: El Burlador de Sevilla, protagonistas femininas, teatro espanhol, conceito de "discreto". 


\begin{abstract}
LUCIANO, F. The Representation of "Discrete": the Commandor's Daughter in 'El Burlador de Sevilla'. 2011. 92 f. Dissertation (Master's degree) - Faculdade de Filosofia, Letras e Ciências Humanas, Universidade de São Paulo, São Paulo, 2011.
\end{abstract}

Using as theoretical and critical references authors like Aristotle, Lope de Vega, Porqueras Mayo, Adolfo Jaime and John Hansen and taking into account the main cultural aspects of the Spanish society during the seventeenth century, this work focuses on the character of Dona Ana Ulloa, daughter of the Commendator in El Burlador de Sevilla, a lady who is seduced and carried out by Don Juan. Its purpose was to understand how the concept of "discreet" was sustained in the Spanish court at that time, trying to clarify the motivations of this attitude in the protagonist's actions, once the social order will be restored through this kind of morality poetics at the end of the dramatic action. For the understanding of the main character's attitude, a discussion - both morally and literarily - was carried out about the concepts and also the connotations of the word "discreet" at that age. This work is divided into three parts. The first one focuses on social, cultural, and historic aspects of the Spanish society during the $17^{\text {th }}$ Century that are present in El Burlador de Sevilla, being alert to the "discreet" as the aspect that differentiates Dona Ana from the other female characters in the play. The second one tries to detach the Commendator's daughter, interpreting her through her incisive attitude and showing how she conflicts with the predominant female profile at that epoch, that is to say, the woman who was treated as an object by men and appreciated because of her beauty, her nobility, and her "readiness" for marriage. Finally, the third part deals with the relationship between Dona Ana and the male characters, through which arises the problem of the representation of "wanting" and "being allowed to", resulting in a double justice: a terrestrial one, administered by the King and reaffirmed by the role of the Commendator; and a divine one, a kind of justice that suggests a catholic ideal of liberty which is personified in the stone guest. So, the protagonist will be struggling between precepts related to a justice of men or a justice of God. The final considerations bind these analyses and conclude for the universality of the female persona that Dona Ana represents, once she is re-created by authors from diverse cultural traditions, as well as diverse epochs.

Keywords: El Burlador de Sevilla, female protagonists, Spanish theater, concept of "discreet". 
1.1 Da manutenção das aparências à ideia de posse do poder de decisão 16

1.2 Entre conceitos: a "honra" e o "discreto" .21

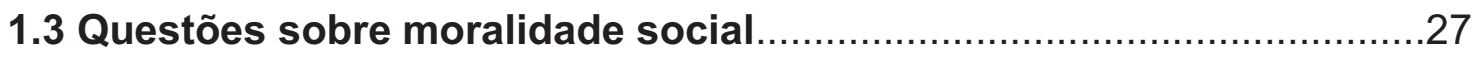

1.40 papel do Rei na hierarquia dos "discretos"......................................32

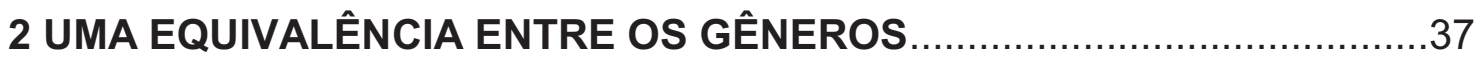

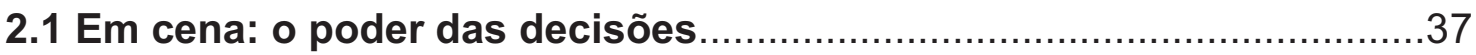

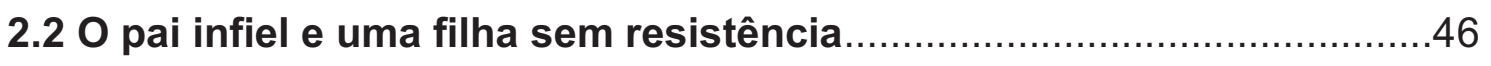

2.3 A Filha do Comendador e as decisões masculinas .............................50

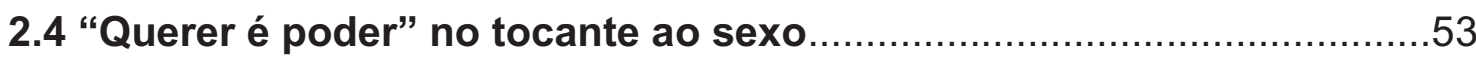

3 A REPRESENTAÇÃO DA FILHA COMO PERSONAGEM NECESSÁRIA..61

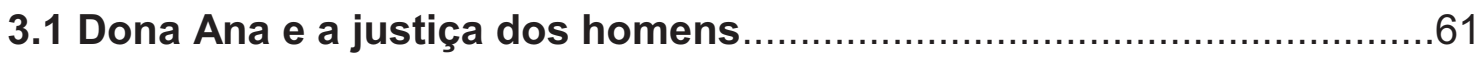

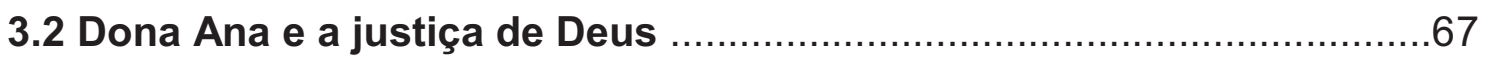

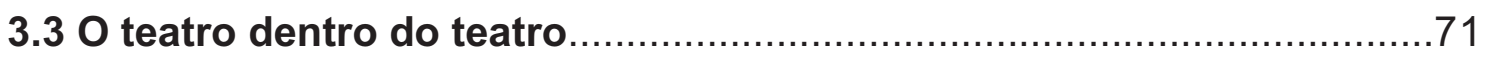

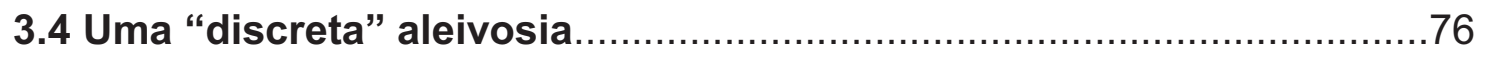

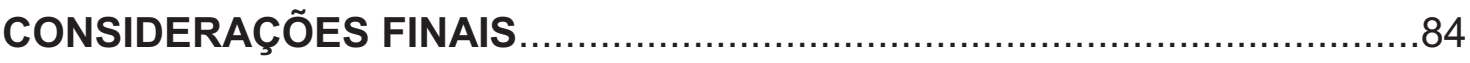

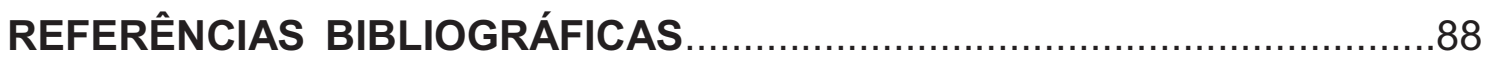




\title{
INTRODUÇÃO
}

\author{
De la vida es un traslado, \\ sustento de los discretos, \\ dama del entendimiento, \\ de los sentidos banquete, \\ de los gustos ramillete, \\ esfera del pensamiento, \\ olvido de los agravios, \\ manjar de diversos precios, \\ que mata de hambre a los necios. \\ $Y$ satisface a los sabios. \\ TIRSO DE MOLINA
}

Este estudo tem como objetivo tratar da atitude discreta da personagem da Filha do Comendador, de El Burlador de Sevilla. São dois os elementos principais que norteiam nosso trabalho e que entrarão em análise: um conjunto de alusões à Filha do Comendador e a cena de seu encontro com Dom Juan e Dom Gonzalo de Ulloa. As alusões são desencadeadas pelas personagens masculinas: o Rei (figura responsável pela garantia da ordem social), o Marquês de la Mota (primo e amante da Filha do Comendador, Dona Ana) e Dom Juan (o sedutor). A cena do encontro, por outro lado, consegue reunir Dona Ana, o sedutor e Dom Gonzalo de Ulloa; cena que levou ao homicídio do pai de Dona Ana, na perspectiva de uma lógica de moralidade.

Para tornar mais precisa a ideia de um perfil de discrição, recorreremos às considerações de João Adolfo Hansen (1991), que servirão de apoio à nossa análise. Isto permitirá centrarmo-nos na ocorrência de uma atitude "discreta" na representação dramática do século XVII.

Quando Hansen escreve sobre a ideia de "discreto" na representação ibérica, notamos que esse conceito se assemelha a um perfil de prudência política, de desprezo pela vulgaridade da plebe, de erudição e de adesão aos 
valores absolutistas. O mesmo autor considera o comportamento "discreto" como típico do ideal católico da Contra Reforma. Neste ideal, as teses neoescolásticas (criticadas pelos "libertinos franceses") compõem justamente o fundamento da prudência política e da discrição, entendidas como católicas, ou seja, conservadoras. Desse modo, o "discreto" do século XVII se destaca por representar um diferencial diante da expectativa proveniente do senso comum acerca do comportamento humano. Tal diferencial está na tendência a orientarse por atitudes que visem a produzir aparências adequadas. Para tanto, há a necessidade de se manter uma conduta judiciosa, propícia à adoção de posturas que possam nutrir, como alicerce natural, uma espécie de opinião pública da época. Por isso, a discrição seiscentista nos permite discutir sobre os excessos que comprometem o plano das aparências, ou seja, as transgressões que atualmente entendemos por "libertinagem"1.

Isso posto, para que se compreenda melhor a expressão dramática do século XVII na Península Ibérica, empregaremos o termo "discreto". Este envolve três posturas: a honra, a reputação e a reverência. Tais posturas tidas muitas vezes como sinônimas e estudadas politicamente como um meio de conquista da opinião geral - serviram-se também das práticas de

\footnotetext{
${ }^{1} \mathrm{O}$ próprio Hansen (Ibid.) mostra que a libertinagem francesa seiscentista se relaciona à ideia de prudência política no século XVII por ser considerada "erudita". Isso porque, de modo polêmico, cita autoridades antigas do relativismo - sofistas, céticos e cínicos - em teses tendencialmente ateias: Protágoras, Epicuro, Sexto Empírico, Lucrécio, Diógenes Laércio, Luciano, Plínio, mas também o Aristóteles da Física, que permite reduzir os fenômenos a causas naturais; Cícero do De Natura Deorum, que permite a crítica da superstitio, e os renascentistas: Pomponazzi, Guicciardini, Maquiavel, Rabelais, Charron, Bodin, Montaigne. Todos estes formam a biblioteca da "filosofia livre" do "homem forte". Assim sendo, compreendemos que todo excesso na articulação dos poderes é produto de uma representação distintiva do privilégio de uma posição superior na hierarquia social: "Embora possa aparecer como 'transgressiva' na situação individual isolada, como é o caso da obscenidade, da pornografia e de práticas eróticas aparentemente muito desviantes, a imagem discreta sempre se adapta aos critérios teológico-políticos institucionais que fornecem a definição contemporânea que integra o sentido da sua representação e ação à hierarquia" (Ibid., p. 79).
} 
representação próprias da época. Desse modo, em El Burlador de Sevilla, a honra é um princípio de referência nas relações sociais que dizem respeito ao estado de ordem vigente. Este deve ser mantido a qualquer preço, até mesmo para a manutenção das aparências, ou seja, para a preservação de tudo aquilo que é concebido como moralmente bom.

É importante destacar, desde já, que a presença de Dona Ana de Ulloa supõe a existência - na sociedade - de uma camada nobre e privilegiada, a qual geralmente detém o poder de decisão. No entanto, a alusão que é feita à nobreza, na peça, acaba por obedecer àquilo que Hansen (1986, p. 99) sugeriu ser uma espécie de "alegoria na submissão do poder". Esta dinamiza a ação dramática e ocorre entre os "iguais", ou seja, entre personagens que integram uma mesma esfera social e que desempenham todos, embora hierarquicamente, o papel de decidir: o Rei ordena, o Comendador legitima tal ordenação, Don Juan decide ignorar a ordem vigente e a Filha representa uma personagem necessária à recomposição da trama por meio de sua atitude "discreta".

Além disso, algo nos leva a crer que o papel de Dona Ana de Ulloa assume uma função peculiar na comédia: o fato de poder decidir-se a favor das coisas por ela cobiçadas. Por meio dessa característica da personagem feminina é que poderemos tratar, em termos comparativos, de uma ação muito próxima ao comportamento comum dos homens de um grupo social privilegiado.

Observamos, no entanto, que o ato de decidir em Dona Ana viabiliza uma interpretação que dá sentido para a inércia do poder masculino, esta que, de certa maneira, se expressa pela incapacidade de transformação dos 
acontecimentos políticos. É nesse aspecto que será possível contextualizar o homicídio da peça, o qual representaria o fracasso da ação terrena de determinado grupo social, composto por homens que decidem pelas causas sociais no intuito de manter-se a ordem. O homicídio vem a ocorrer após o encontro de Dom Juan com Dona Ana; seu desfecho, corroborado com a posterior presença do Convidado de Pedra, tende a estabelecer um vínculo com o extraterreno. Haveria aqui elementos delineadores de um retrato do poder exercido por um ser humano que se encontra fragilizado. Pois esse poder de decisão se concentra em uma classe privilegiada, porém tendenciosamente imitadora da figura do monarca, para que a ordem que a privilegia seja mantida a qualquer preço. Consequentemente, as decisões da nobreza já não eram tão eficientes em função da desordem social estabelecida pelas ações de Dom Juan. Com isso, o poder sobrenatural parece representar um meio alternativo - adotado pelo dramaturgo - contra o descontrole político que pairava sobre a sociedade.

Cabe ainda observar que em El Burlador de Sevilla, Dona Ana de Ulloa é mencionada pelos homens como um "objeto" em tudo o que diz respeito à apreciação de sua extrema beleza, nobreza e casamento. Diante disso, percebemos que sua "discreta" atuação abre espaço para uma igualdade do poder de decisão entre homem e mulher pertencentes a um mesmo status social.

Não podemos perder de vista que o Rei utiliza seu poder de decidir a favor da preservação da ordem. Assim, por um lado se representa a figura do real em seu poderio absoluto, ainda que fragilizado; por outro, verifica-se na personagem da Filha do Comendador uma individualidade em que o poder de 
decidir se encaminha conforme suas vontades e necessidades, o que a destaca duplamente: em sua postura de mulher cortesã e na condição de alegoricamente submissa, para retomar o que diz Hansen (op. cit.).

Portanto, para exemplificar a ação de uma personagem com vontade própria - apesar de submetida a uma hierarquia de valores da nobreza, como é o caso da Filha - serão discutidos alguns aspectos discursivos que ora equivalem aos elementos linguísticos persuasivos, ora apontam para valorização de uma personagem necessária à trama.

Em nossa análise, tomaremos como referencial teórico de criação literária a Poética, de Aristóteles; El Pinciano y las Teorías Literárias del Siglo de Oro, de Sanford Shepard; Arte Nuevo de Hacer Comedias, de Lope de Vega, e a Preceptiva Dramática del Siglo de Oro, de Porqueras Mayo. Com tal sustentação teórica, consideraremos também alguns aspectos da sociedade espanhola, tal como nos é apresentada em El Burlador de Sevilla (ou seja, alicerçada na noção de honra) e aludiremos a alguns acontecimentos históricos que possibilitarão discussões sobre as relações de poder. Faremos isto a partir do livro de Jaime Cortesão, A Política de Sigilo nos Descobrimentos, por se tratar de obra que fornece alguns subsídios para entender como o perfil de discrição se sustentava na sociedade da Corte (ponto que acaba por condicionar a ação dramática nesta peça).

Enfim, o conceito e as conotações do termo "discreto", na época de El Burlador de Sevilla, precisam ser discutidos, seja no âmbito do enaltecimento da prudência, da produção de aparências adequadas ou das ordenações cortesãs; seja, ainda, no tocante a outras expressões literárias, que serão apontadas a título de comparação. 
Assim, entender alguns aspectos da cultura política e literária da época será útil para nossa abordagem, principalmente no que diz respeito aos elementos constitutivos do cenário que favoreceu a construção da personagem da Filha.

Para efeito de análise, como dissemos no início, observaremos, além da cena do encontro entre Dona Ana e Dom Juan, as menções à Filha que são feitas na peça pelas personagens do Rei e do Marquês de la Mota (este último, primo e amante de Dona Ana). Serão discutidas as ações articuladas pela figura do monarca no parâmetro de ordem/desordem social e no contexto de uma "alegoria na submissão" - como já vimos que sugere Hansen - além de referências ao comportamento ditado por um código de honra. Isso permitirá discutir o papel da Filha, tanto em seus elementos constitutivos quanto na equivalência do poder de decisão que lhe é atribuído. Este se configurará como uma forma peculiar de discurso de mando, típico das personagens masculinas. Discurso, cuja condução moral será aqui articulada pela personagem necessária à lógica de equilíbrio social, em conformidade com a mentalidade da época. Tal seria Dona Ana de Ulloa. 


\section{A PERSONAGEM DA FILHA NA PERSPECTIVA DO “DISCRETO”}

Neste capítulo serão discutidos alguns fatores de caráter histórico e social presentes no texto de El Burlador de Sevilla. Indicaremos uma linha de raciocínio que nos permitirá esclarecer aquilo que entendemos como "discreto" no que diz respeito à Dona Ana de Ulloa, característica capaz de diferenciar a mesma das demais personagens femininas da obra. Pensaremos sobre alguns dos fatores que podem ter motivado o dramaturgo, ao compor o papel da Filha do Comendador. Nesse âmbito, a cena será articulada pela ação de "querer", tratada como sinônimo de "poder decidir" ou mesmo "tomar decisão". Isto nos possibilita identificar uma atitude comum na representação das personagens masculinas do século XVII e acaba por nos apresentar um perfil de autoridade por meio da figura feminina em estudo.

\subsection{Da manutenção das aparências à ideia de posse do poder de decisão}

Primeiramente, quando empreendemos uma análise de El Burlador de Sevilla voltada para a leitura da personagem da Filha do Comendador, devemos esclarecer aquilo que se refere ao seu modo de agir no decorrer deste capítulo. No tocante à ação "discreta", Hansen (1991, p. 79) nos ajuda a configurar a ideia que se tinha de discrição na época de El Burlador de Sevilla. Com base nessa conceituação, buscaremos compreender a razão de uma atitude "discreta" da Filha diante de um poder político que teve sua eficácia questionada por muitos críticos no terreno da literatura, mas que também serviu de fonte de elevada expressão dramática na Espanha do século XVII. 
Podemos dizer que, a partir do século XVI, esse país esteve sujeito a uma forma de monarquia onde a vontade do Rei estabelecia os limites das leis. Sendo assim, justamente no tocante à legislação, o monarca acaba por ser confundido com o Estado. Ocorria, para tanto, uma espécie de personificação do poder, na figura do Rei. O soberano assume um poder total - e ostenta as aparências desse poder - em virtude de prerrogativas pessoais, de autoridade própria, ou, ainda, em virtude de se identificar com as leis, que interpreta ou aplica. Notamos, assim, a incidência de uma política de aparências, em pleno sistema político do, até então, Estado Absolutista. Isso será importante para elucidar depois algumas questões.

El Burlador de Sevilla é uma peça teatral atribuída a Tirso de Molina. Embora representada originalmente em três jornadas e ao ar livre, observamos, também, que suas numerosas cenas foram, algumas vezes, apresentadas sem interrupção e sem cenário. A ação dramática remete ao quadro histórico do século XIV e se desenvolve de Nápoles ao litoral da Espanha, dentre outros lugares, até fixar-se em Sevilha, onde se localizava o palácio do Rei de Castela.

Em Nápoles, o monarca ordena a Dom Pedro Tenorio - o tio de Dom Juan, também embaixador espanhol naquela Corte - que prenda o responsável por uma ofensa. O soberano recomenda que essa prisão seja secreta, a fim de evitar o escândalo e salvaguardar a honra da Duquesa Isabela. Vejamos a recepção desse acontecimento em Castela:

\section{Rey}

¿Que esto pasa? 


\title{
Don Diego Tenorio
}

Señor, esto me escribe de Nápoles Don Pedro, que le hallaron con dama en el Palacio, $\underline{y \text { apercibe }}$ remedio en este caso ${ }^{2}$.

Começa aqui a observar-se que, em El Burlador de Sevilla, a honra é um princípio de referência nas relações sociais e também se relaciona ao estado de ordem da sociedade. Esse princípio deve ser mantido sempre, inclusive para a manutenção das aparências:

\begin{abstract}
No mais, cumpre argumentar a partir dos desejos e das opiniões expressas, pois o que se deseja e o que se exprime não é o mesmo: exprimimos o que tem uma aparência mais decente, enquanto se não deseja senão o que parece mais em conformidade com os próprios interesses; por exemplo, dizemos que uma boa morte vale mais do que uma vida gozosa, e uma pobreza honesta mais do que uma riqueza vergonhosa, embora na realidade desejemos todo o contrário (ARISTÓTELES, 2000, p. 104).
\end{abstract}

Alonso López, mais conhecido pelo gentílico Pinciano (1997), publicou, em 1596, a primeira poética nacional. O autor está em conformidade com o conceito aristotélico acima referido, alertando que é preciso preservar um elevado caráter moral, geralmente associado ao elemento aristocrático. No entanto, ainda que Pinciano aponte para uma ordem social centrada naquilo que é tido como "moralmente hermoso, bueno y noble" (SHEPARD, 1970, p. 82-83), é preciso dizer que Aristóteles, segundo a interpretação mais comum, faz referência à excelência de caráter, legitimado pela aristocracia. Assim, cabe-nos dizer que essa classe social, que culmina no trono da monarquia, detém poder e é reconhecida pelos súditos por sua excelência de caráter.

\footnotetext{
${ }^{2}$ Versos 1089-1093 (grifo do autor deste trabalho). Todas as citações de El Burlador de Sevilla foram retiradas e referenciadas apenas pelos números dos versos desta edição.
} 
Portanto, é admissível que El Burlador de Sevilla seja um pretexto bem oportuno do dramaturgo para colocar em evidência não uma questão de caráter (cuja excelência não se contestava), mas a ação de mando - que se revela subjetiva - dessa camada privilegiada e poderosa, que se fragilizava socialmente em nome de uma política de aparências.

A esse respeito, haja vista a ação de Dom Juan no início da peça: retira a máscara e confessa ter fingido ser o Duque Octavio - inclusive após possuir a Duquesa Isabela - mas nada disso afeta seu tio, Dom Pedro Tenorio, que simula não saber que o intruso era, na realidade, o próprio sobrinho. Contudo, temeroso de ser responsabilizado, tanto pela ofensa cometida à Duquesa Isabela quanto pela profanação do palácio do Rei, Dom Pedro desafia Dom Juan a um duelo. Ao perceber que o desafiado se recusa a lutar contra 0 próprio tio, Dom Pedro ajuda-o a fugir e o aconselha a buscar um refúgio em Milão ou na Sicília.

Em contrapartida, o mesmo Dom Pedro Tenorio relata ao Rei a dura luta que fora travada com o "intruso" e como este, ao final da empreitada, tinha conseguido escapar. Então o monarca ordena a prisão da Duquesa Isabela e do Duque Octavio que, segundo a denúncia de Dom Pedro, tinham sido responsáveis pela antecipação dos ritos matrimoniais (muito embora o Duque Octavio tivesse fugido para Espanha).

Nesse sentido, percebemos o quanto os relatos entre os nobres ligados à mesma ordem de convívio social funcionam como gênero discursivo que corrobora uma política de aparências. Graças a esses relatos se alcançava obscurecer a identidade dos infratores responsáveis pela desordem social 
instaurada, pois estes se inserem nessa mesma camada social privilegiada, e a revelação culminaria em um escândalo que abalaria a todos.

A propósito da manutenção de uma política de aparências, fica bastante evidente que entre os nobres portadores de poder de decisão acerca das questões sociais, parecia haver um "acordo comum", responsável por garantir o status quo da categoria social a que pertenciam e que é referenciada na peça. Já no palácio do Rei em Sevilha, o relato ganhará uma conotação de virtude e servirá para uma elucubração do Comendador Dom Gonzalo de Ulloa ao se referir aos bons resultados alcançados em sua missão a Portugal. Esse Comendador, renomado e muito distinto, era o pai de uma única filha, a bela Dona Ana de Ulloa. Consequentemente, a fim de recompensar ao Comendador, o Rei daria um dote a sua filha para que ela se casasse com Dom Juan Tenorio. Porém, ao saber do ocorrido em Nápoles, por meio de Dom Diego Tenorio, ministro da justiça que Ihe relatava os malfeitos realizados por Dom Juan, o soberano decide que o transgressor deve se casar com a desonrada Duquesa Isabela e que o mesmo deverá ser afastado da Corte até que se realizem as núpcias. Logo, ao fazer valer uma política de "ajustes", com intuito de reparar o erro cometido contra o Duque Octavio, o monarca decide que Dona Ana de Ulloa será a prometida do duque.

Convém lembrar que a presença da Filha do Comendador supõe a representação de uma parcela nobre e privilegiada da sociedade que detém o poder de decisão. Por essa razão é que se modelará uma atitude "discreta" dessa personagem. Tal ação, por sua vez, possibilitará a leitura da representação de uma poética de moralidade, para que ocorra apenas o 
restabelecimento da ordem social ${ }^{3}$. Em busca de uma tão almejada ordem na sociedade, concorrerão fatores como a hierarquia e a submissão por serem responsáveis pela sustentação das relações de poder. Assim, entre os "iguais" estão as personagens da nobreza inseridas no meio social retratado na peça. Isso feito por meio de uma alegoria da submissão do poder (HANSEN, 1986): da ordenação do monarca se sustenta uma legitimação alinhavada pelo Comendador, ignorada por Dom Juan e direcionada a um fundo moralizante por meio da aparição da Filha do Comendador que, discretamente, contribuirá para preservação da ordem.

\subsection{Entre conceitos: a "honra" e o "discreto"}

Antes de prosseguirmos, faz-se necessário compreender alguns aspectos que melhor elucidam ou motivam o processo de construção da personagem de Dona Ana de Ulloa. Reiteramos que a base que viabiliza nossa leitura, naturalmente, estabelece-se em meio a esse poder de decidir que caracteriza uma aristocracia forte, um grupo social cuja postura predominante visa a garantir uma atitude de aparente adequação a um código de honra.

Observamos que muitos estudiosos discutiram bastante os conceitos das palavras honor e "honra" devido a sua grande importância no teatro clássico espanhol. Na maioria dos casos, a ideia de honor alude à dignidade do indivíduo, ao passo que "honra" corresponde ao respeito que a sociedade deve a ele (RUIZ RAMÓN apud PEDRAZA JIMÉNEZ e RODRÍGUEZ CÁCERES, 1995). Assim, para Ruiz Ramón (Ibid.) a palavra honor possui uma dupla

\footnotetext{
${ }^{3}$ No entanto, não significa que haja uma preocupação com o caráter. Isso, como dito anteriormente, já estava consolidado entre os súditos da nobreza, ou seja, a excelência de caráter era concebida como o esperado para aqueles governantes que detinham o poder de decisão. Por isso, insistimos na ideia de uma classe dominante desunida e aparentemente eficaz.
} 
dimensão. Se, de um lado, também faz referência ao sentimento da própria dignidade, sendo defendido até a morte pela personagem, por outro, representa uma dimensão que está ao alcance de todos, desde el rey al villano. Nesse sentido, entendemos também que o respeito à pessoa se torna algo sagrado, pois essa ideia sustenta a acepção de dignidade como um atributo cuja origem é divina. Logo, o Rei funcionaria como uma espécie de árbitro de autoridade divina e acabaria por sancionar os atos que, em defesa de seu honor, as personagens levariam a cabo, visando à manutenção dessa ordem. Portanto, para que possamos refletir sobre o código de honra no contexto da peça, verifica-se que a honra nos é apresentada como um modelo de conduta geral a ser seguido. Assim, em conformidade com Aristóteles, Pinciano (apud. SHEPARD, 1970) menciona uma ação que obedece a um processo interno ao indivíduo e que se exterioriza a partir de seu comportamento social, ou seja, apresenta um tipo de comportamento padrão a ser seguido, o qual é marcado pelas repercussões alcançadas na opinião dos outros homens.

Para Aristóteles, ser glorificado não era uma virtude em si, mas uma recompensa social por atos virtuosos ou heróicos. Porém, por volta do século $\mathrm{XVI}$, observamos que o senso comum tinha como referência a época dos duelos ${ }^{4}$, culminando com uma visão de honra que significava não apenas um mérito externo, como também interno. Por exemplo, um cavaleiro era considerado um herói não somente por seus feitos, mas também por sua gentileza e nobreza de espírito. Sendo assim, sua honra podia ser maculada

\footnotetext{
${ }^{4}$ Consoante a isso, cabe lembrar que o termo "duelo" remonta o período das justas que ocorriam na Idade Média, contribuindo com uma espécie de "imaginário coletivo" instaurado na Península Ibérica do século XVI. A partir de então, convém associar o desenvolvimento dos códigos - oriundos dos duelos - pode estar relacionado ao princípio de honradez praticado pelos cavaleiros nobres cuja nobreza de espírito contribuía e enaltecia o caráter virtuoso do cavaleiro (tido como herói) e isso acabava por espelhar um modelo de conduta da sociedade que é retratada em El Burlador de Sevilla.
} 
por outros através do adultério, da injúria ou outros crimes, e defendê-la perante os olhos da sociedade era necessário. Já o termo honor se usa em outra acepção de honra. Esta, no tocante à esfera social, também apresentaria uma dimensão diacrônica, que a liga à linhagem familiar da pessoa, e ainda uma dimensão sincrônica, que faz referência ao bom nome que liga a pessoa a sua comunidade. Em linhas gerais, entendemos que alguém "desonrado" desonra também sua família e sua cidade. Logo,

\begin{abstract}
La causa más común de la deshonra, en la estructura dramática de la comedia, es de orden erótico y sexual. Concebida la mujer como una pertenencia, la seducción de la soltera por el galán o el adulterio de la casada constituyen un despojo que el pater familias (padre, hermano o marido) no puede consentir. Las leyes del honor son rígidas a ese respecto: el agraviado ha de tomar inmediata venganza, si la ofensa es pública; o mediata y meditada, si el agravio es secreto (PEDRAZA JIMÉNEZ e RODRÍGUEZ CÁCERES, 1995, p. 88).
\end{abstract}

Nesse aspecto, percebemos que a honra espanhola se relaciona ao honor clássico, pois ambos zelam pela boa reputação de alguém como reconhecimento público de suas qualidades ${ }^{5}$. Essa honra de caráter coletivo tornou-se mais perceptível, desde então, na honra depositada na mulher, enquanto portadora da honra dos homens da família, especialmente o pai e o marido, ou "[...] la sociedad retiraba toda consideración al individuo que no siguiera puntualmente las sangrientas normas del código del honor" (Ibid., p. 89).

\footnotetext{
${ }^{5}$ Reiteramos que o termo "qualidade" supõe atitude e, nesse caso, faz referência à manutenção de uma postura, de uma reputação, não se referindo a uma subjetividade no tratamento do caráter em relação às personagens da peça. Isso porque nossa reflexão não tem por objetivo questionar o caráter da nobreza, mas sim configurar o cenário em que se processava uma política de ajustes ante um código de honra. Igualmente frisamos que nossa ideia é delinear os fatores que serviram como reflexo social na construção da peça, sendo uma possível justificativa quanto à presença da personagem da Filha do Comendador no enredo.
} 
Com isso, torna-se possível compreender um tipo de comportamento "discreto" da nobreza, que preza ferrenhamente sua reputação, fazendo enorme investimento na manutenção das aparências. Isso é feito a fim de se evitar uma punição que tinha no código de honra o fundamento do reconhecimento social ${ }^{6}$. Assim, para que possamos entender a atitude da Filha do Comendador, valemo-nos novamente da ideia que se expressava com o termo "discreto", pelo qual, segundo Hansen (1991), a sociedade do século XVII indicava três posturas: a honra, a reputação e a reverência. Ou seja, o "discreto" é aquele que mantém uma representação adequada às posições e aos cargos que ocupa, evitando a todo custo a murmuração. Em El Burlador de Sevilla, tal procedimento se instaura ao manterem-se intactas a honra e a reputação das figuras da nobreza explicitadas na representação, bem como a reverência e a obediência que lhe são devidas. Tanto a honra quanto a reputação e a reverência são atitudes quase sinônimas, pois entendemos que as mesmas detêm um elevadíssimo grau de importância nos ditames sociais e são processadas hierarquicamente no convívio social. Logo, cabe reiterar nosso apontamento no que diz respeito à ideia de que essas ações eram doutrinadas politicamente, como um meio de formação de opinião, nas práticas de representação da época.

Ao fim, notamos o quanto a opinião coletiva no século XVII funcionou como um mecanismo de sanção social, por meio do qual se precisavam as questões ligadas à honra e à desonra, ou seja, funcionou como força que sempre revigorava a necessidade de uma manutenção das aparências. Isso

\footnotetext{
${ }^{6}$ Cf. SHEPARD, Sanford. El Pinciano y las Teorías Literarias del Siglo de Oro. Madrid: Gredos, S. A., 1970, p.82, tal reconhecimento ilustra aquilo que é concebido como "moralmente bom" e que, em uma primeira instância, reflete o caráter moral e não necessariamente a posição social.
} 
desencadeia toda uma "moral da aparência" e uma "aparência da moral" a fim de que se represente a honra.

Entendemos por "moral da aparência" a atitude "discreta" da nobreza, representada em El Burlador de Sevilla e consistente ao preocupar-se somente com a preservação exterior da honra. O objetivo de tudo isso era impedir que sua reputação fosse abalada. Enfim, representa-se a realidade da maneira mais adequada e de modo a não comprometer o prestígio da nobreza.

No tocante à "aparência da moral", cabe dizer que será neste momento que nos colocaremos na posição do espectador da peça teatral, pois aparentemente o dramaturgo oferece a este uma espécie de retrato da moral que os homens nobres e detentores do poder quiseram legar à posteridade. Tal retrato é feito a partir do cenário do século XIV, mas as preocupações que o inspiram se articulam e culminam no próprio século XVII. A nobreza constituía uma porção privilegiada da sociedade, que detinha e articulava um poder de decisão. Como as aparências de dignidade eram fundamentais na manutenção de seu status, foi nesse sentido que esse grupo social buscou mantê-las a todo custo. Embora se vislumbre sempre uma classe forte, devemos ter em vista que a categoria dos nobres se vê de certa maneira corrompida, ao estar representada por indivíduos temerosos de abalarem sua reputação, fragilizando-se pela desunião de seus componentes, a despeito de os mesmos se servirem da discrição no exercício aparente do código de honra.

Partimos disso para que melhor se analise a atitude que move a ação da Filha do Comendador como portadora da honra de seu pai. O que acaba de ser exposto permite dizer que o termo "discreto" se aplica à atitude de Dona Ana de Ulloa, quando esta manifesta o desejo de que se realize o encontro 
amoroso com o primo, o Marquês de la Mota. De fato, inquieta pela condição de sujeito passivo diante da decisão de seu pai, a Filha assumirá uma postura "discreta".

\section{Dona Ana}

Mi padre infiel

en secreto me ha casado

sin poderme resistir ${ }^{7}$.

Devido à falta de resistência aberta, ou mesmo por força de uma inquietação interior provocada pelo poder de decidir - que os pais têm sobre suas filhas ${ }^{8}$, é que se estabelece e se desenvolve a ação "discreta" de Dona Ana. Ou seja, diante do agir da Filha do Comendador, é possível observar as pulsões análogas que motivam também as personagens masculinas da peça, no que se refere ao procedimento discreto. Tal procedimento é capaz de ocultar o verdadeiro "eu" pessoal, a fim de favorecer a concretização daquilo que se cobiça. É nesse sentido que a leitura da discrição da personagem da Filha pode estar associada à expressão de poder masculino proveniente da camada privilegiada, tal como proposta na comédia.

Observamos, ainda, que a discrição de Dona Ana nos revela uma atitude mais incisiva em seu querer. Por esse querer, a personagem acaba por

\footnotetext{
${ }^{7}$ Versos 1361-1363.

${ }^{8} \mathrm{Cf}$. OROZCO DÍAZ, Emilio. El teatro y la teatralidad del barroco. Barcelona: Editorial Planeta, 1969 , p. 21, ao mencionar os traços estilísticos típicos da produção cultural do século XVII e que se identificam com a comédia, notamos que tal posicionamento acaba por corroborar um mundo de fingida realidade, instável e capaz de gerar inquietud, ou seja, a resistência da Filha gera "una íntima inquietud de que en el fondo, y como causa de ese dinámico desbordamiento de falso fuego teatral, hay una honda verdad, algo en ascuas que produce ese incendio cuyo calor nos llega al alma, pues es el calor de la vida, de esta vida que ha de pasar con sus seducciones como si solo fuese teatro". Portanto, entendemos que a referência ao "falso fogo teatral" ilustra a situação contingente que é transferida à personagem da Filha. Trata-se de uma espécie de angústia contra o mundo aparente que muito alimentou as ações de Dom Juan, atitude mais comum às personagens masculinas.
} 
conduzir os homens aos desfechos quase trágicos, resolvidos apenas no plano do divino.

\subsection{Questões sobre moralidade social}

Curiosamente, o crítico literário Ruiz Ramón (apud. PEDRAZA JIMÉNEZ e RODRÍGUEZ CÁCERES, 1995) destaca a ausência de um sentido de moralidade nas personagens de El Burlador de Sevilla. No entanto, se levarmos em conta a situação da Duquesa Isabela, percebemos que ela não duvidou em procurar o Duque Octavio, apesar de saber que não era ele o autor de sua desonra. Lembre-se que, Dom Pedro Tenorio, sabendo a verdade a respeito do que ocorrera em Nápoles envolvendo a duquesa, descaradamente, detém o inocente Duque Octavio. Portanto, tudo nos leva a crer que a peça enfatiza o grande cuidado da nobreza com a manutenção das aparências.

Torna-se bastante evidente que, entre a nobreza, o poder de decisão é um fator que não deve ser comprometido e que vai muito além da qualidade moral que se pretende espelhar na peça. Na verdade, agir "discretamente" supõe uma espécie de fuga perante a situação dilemática vivida pela personagem e isso the confere algumas ações inesperadas, como é o caso da Filha do Comendador. Por meio desta personagem, colocamo-nos diante da prefiguração de uma atitude capaz de levar o espectador a reconhecer diferentes qualidades na ação, o que às vezes pode resultar na concepção de caráter um tanto extremista, ou ainda, por meio da qual se possa entender se o indivíduo é feliz ou mesmo infeliz no contexto de um sistema de ordem a ser respeitado por todos. Enfim, isso nos revela a ideia de que satisfazer um desejo exige manter as aparências: "Os homens possuem diferentes 
qualidades, de acordo com o caráter, mas são felizes ou infelizes de acordo com as ações que praticam" (ARISTÓTELES, 2000, p. 44).

Sendo assim, para Aristóteles, as ações e a vida humana se passam em um mundo onde é necessário apenas realizar determinadas opções para que, como dissemos anteriormente, o indivíduo seja feliz ou infeliz. Disso decorre uma preocupação ética com os heróis e uma atenção analítica às circunstâncias cênicas e da decisão, o que nos remete novamente ao ato de fingir no século $X V I^{9}$. A partir desse ato, o indivíduo, por meio de sua ação dramática, é um fingidor ao buscar satisfazer seu desejo. Assim, na figura do monarca encontramos a representação da luta constante pela preservação da ordem social. Por isso, o soberano é tido como aquele que propõe resoluções em favor do bem da coletividade. Dom Gonzalo (o Comendador) deve servir ao Rei e, para isso, luta em nome da tradição de se preservar a honra da família. Dom Juan almeja seduzir e, para tal, sempre atua contra a situação que lhe é imposta. Já, Dona Ana, esta se encontra em pleno dilema por ter de seguir a ordem do pai, o que lhe conduz a uma ação contingente e, ao apresentar uma reação inesperada para uma figura feminina da época, destaca-se por assemelhar-se às atitudes masculinas. Para tanto, a personagem opõe uma resistência contra o que não está de acordo com seus anseios e suas vontades. É desse modo que a Filha do Comendador desejará o encontro com o primo, o que colocará em prova sua honra condicionalmente abalada após a sedução de Dom Juan.

\footnotetext{
${ }^{9}$ Nesse caso, é importante que tenhamos em mente o cenário político no qual transcorre a ação da peça (século XIV) e o cenário de uma política orientada pela manutenção das aparências (século XVII). Os dois períodos carregam as pulsões humanas norteadas por um código de honra que culminem em dilemas humanos. El Burlador de Sevilla nos apresenta uma corte cujo exercício do poder titubeia e se mantém pela conformidade das aparências por meio das relações interpessoais ali estabelecidas hierarquicamente entre aqueles que compõem a camada da nobreza.
} 
Segundo Prado (In: CÂNDIDO, 2004), o mais eficaz é a personagem que nos transmite sua natureza através das ações. Por isso, em El Burlador de Sevilla as tais ações podem ser descritas de três modos, por meio dos quais proporemos a configuração das qualidades que são atribuídas à Filha do Comendador.

$\mathrm{Na}$ descrição de suas ações - por exemplo, no bilhete enviado ao Marquês de la Mota - cabe observar os verbos empregados no modo imperativo, no caso "muéstralo" e "ven":

\section{Dona Ana}

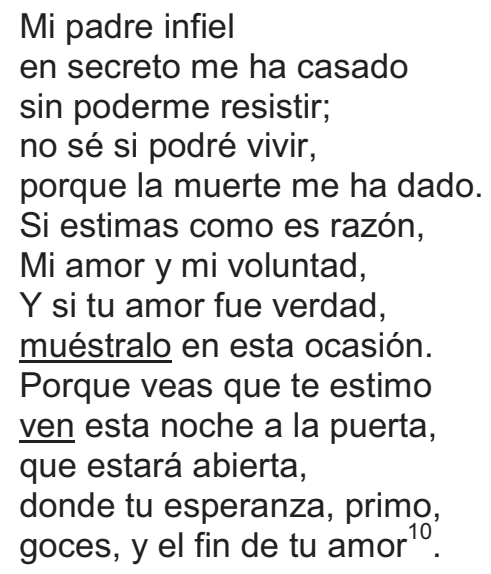

Ao falar de si mesma - quando Dona Ana reivindica uma providência em relação ao assassino de sua honra - a personagem questiona a existência de um "quién" responsável pela manutenção da ordem social:

\section{Doña Ana}

¿No hay quien mate este traidor Homicida de mi honor? ${ }^{11}$

\footnotetext{
${ }^{10}$ Versos 1361-1374 (grifo do autor deste trabalho).

${ }^{11}$ Versos 1610-1611 (grifo do autor deste trabalho).
} 
Por fim, há o que dizem os outros a seu respeito - os homens (tanto o pai, Dom Gonzalo, quanto o primo). Todos eles mencionam a perfeição da beleza de Ana e acabam aproximando-a da Natureza:

\author{
Mota \\ Es extremada, \\ Porque en Doña Ana de Ulloa \\ Se extremó Naturaleza. ${ }^{12}$ \\ Don Gonzalo \\ Gran señor, \\ Una hija hermosa y bella, \\ En cuyo rostro divino \\ Se esmeró Naturaleza ${ }^{13}$.
}

Desse modo, tudo nos leva a crer que a ação de Dona Ana de Ulloa está articulada por um elemento peculiar na obra dramática. Trata-se daquilo que normalmente se revela pelo fato de esta personagem feminina se distinguir das demais mulheres pelo poder de decidir pelas coisas cobiçadas. Mesmo assim, não podemos perder de vista que "[...] caráter viril existe, mas à mulher não convém ser viril ou terrível [...]" (ARISTÓTELES, 2000, p. 54).

Com base nestas palavras aristotélicas é que melhor entenderemos a presença de Dona Ana na trama da obra atribuída a Tirso de Molina. Assim, associamos o caráter viril da Filha do Comendador a uma maneira de agir que tende a caracterizar um comportamento exterior comum entre os homens "discretos" da nobreza - ao passo que, interiormente, as personagens são movidas pelas diferentes tendências, que acabam por explicar suas atitudes:

\footnotetext{
${ }^{12}$ Versos 1304-1306 (grifo do autor deste trabalho).

${ }^{13}$ Versos 906-909 (grifo do autor deste trabalho).
} 
Quatro pontos devem ser visados quando se trata dos caracteres. $O$ primeiro e o mais importante é que eles sejam bons. Existe caráter, como antes dissemos, quando as palavras e as ações revelarem tendências; se estas forem boas, bom será o caráter. Essa bondade pode estar em todos os tipos de personagens, incluindo a mulher e o escravo, ainda que a mulher seja inferior e o escravo, insignificante (Ibid., p. 54).

$\mathrm{Na}$ verdade, o que decorre do homicídio praticado após o encontro de Dom Juan com Dona Ana aponta para um retrato de uma aristocracia que sempre decide pelas causas que Ihe são mais oportunas e que detém (por meio da figura do monarca) o pretexto para a manutenção da ordem social.

\author{
Rey \\ No es bien que el Duque Octavio \\ Sea el restaurador de aqueste agravio. \\ Doña Ana, con la Reina, me ha pedido \\ Que perdone al Marqués, porque Doña Ana, \\ Ya que el padre murió, quiere marido, \\ Porque si le perdió, con él le gana. \\ Iréis con poca gente, y sin ruido \\ Luego, a hablarle a la fuerza de Triana. \\ Por su satisfacción, y por abono \\ De su agraviada prima, le perdono ${ }^{14}$.
}

Em tese, é nesse ponto que se instaura uma possibilidade de se preservar a ordem de qualquer modo. Há aqui um fator principal, que ilustra o quanto o mundo terreno já não dava mais conta dessa manutenção social, pois as aparências se fazem enganosas. Esse engano provocado pelo aparente leva a um caminho sem precedentes, no qual a descrença no ser humano impõe à trama a necessidade de uma intervenção divina. Tal processo nos homens desestabiliza o poder de decisão no universo terreno, onde terá de haver a intervenção do sobrenatural (por meio do Convidado de Pedra).

\footnotetext{
${ }^{14}$ Versos 2064-2013.
} 
Ainda que aparentemente, o Rei se utiliza de seu poder de decidir a favor da preservação de uma sociedade aparentemente justa. Categoricamente, no entanto, a peça retrata a Espanha caracterizada por uma antiga tradição teatral moralizadora, cujo componente social se vê despreocupado com uma moral efetiva ${ }^{15}$. Nesse sentido, o próprio Rei cierra los ojos e delega suas responsabilidades a outros. Sobre essa atitude da realeza, Ignacio Arellano menciona que

[...] hay una dura crítica contra el rey, los privados, y la general degradación. El rey Don Alfonso solo es capaz de castigar a Don Juan desterrándolo a Lebrija, pueblo a un paso de Sevilla, destierro que Don Juan no respeta. Conforme se acumulan más detalles de los abusos de Don Juan, la ira del rey sólo alcanza, con total injusticia, a hacerlo conde en su lugar de destierro (ARELLANO, 1995, p. 349).

Por um lado se representa a figura do soberano em seu poderio absoluto. Por outro, na personagem da Filha se verifica uma atitude "discreta", na qual o poder de decidir se viabiliza conforme suas vontades e necessidades. Isso a destaca em sua atuação contingente, apresentando, desde então, uma postura só externamente submissa aos patamares de uma sociedade naturalmente hierárquica.

\subsection{O papel do Rei na hierarquia dos "discretos"}

Vimos que a tomada de decisão é um ponto comum entre os homens da aristocracia. Com base nisso, devemos estar atentos ao universo social da época. O dramaturgo o retratou expressando uma grande desconfiança no ser

\footnotetext{
${ }^{15} \mathrm{Em}$ certa medida, El Burlador de Sevilla, como boa parte da produção dramática do Siglo de Oro, supõe uma atualização das antigas moralidades medievais, peças constituídas por longos diálogos entre tipos alegóricos, no sentido estrito do termo, de vícios e virtudes.
} 
humano. Sabemos que havia um sentimento geral que depositava no Rei grande parte das reivindicações coletivas. Por isso, muitos críticos literários entre os quais Ruiz Ramón (1971) e Varey (1987) - vieram confirmar o que há muito tempo se verificava nas considerações de cunho histórico quanto a este ponto. Assim, no que diz respeito ao papel do Rei em El Burlador de Sevilla, lembremos algumas das funções que Ihe são atribuídas: exercer a realeza como expressão da prudência, centrar em seu cargo todo poder e honra (de modo a fundamentar a justiça e a ordem), premiar ou castigar (e para tanto, manter distância em relação ao caos humano), espelhar a divindade, realizar uma política de "ajustes" em nome da ordem, impor o despacho favorável a uma petição e restaurar a harmonia social.

Desse modo, podemos notar o quanto a nobreza "se empenha" no intuito de manter certo tipo de enaltecimento da monarquia enquanto instituição, buscando ser também representante das máximas virtudes. Nossa visão, no entanto, pretende apresentar ideias que tendem a evidenciar 0 trabalho dramatúrgico na perspectiva da criação de uma personagem de grande relevância. Personagem atuante em um contexto social que visa a mascarar ou idealizar a realidade. Identificamos uma expressão muito clara dos ideais dos setores dirigentes ao servir ou mesmo legitimar seus privilégios.

Sendo assim, não podemos perder de vista que a figura do monarca está no ápice da hierarquia social, em cargo que reúne o poder e toda honra a ser resguardada. Cabe a ele reverberar constantemente o exercício da prudência aos seus súditos ${ }^{16}$. Por isso devemos extrair do papel do Rei no

\footnotetext{
${ }^{16}$ Nesse caso, os seus "iguais" (portanto, referimo-nos à nobreza), já que, cabe à nobreza ter uma função exemplar ou mesmo didática. Ainda que encontremos casos particulares de nobres de moral deturpada como os comendadores que aparecem em Peribáñez o Fuente Ovejuna, de Lope de Vega, esses nobres são tidos como elementos indignos ou mesmo infiéis em sua
} 
drama uma ideia de instância superior que iguala todos e que é capaz de encarnar uma política aparentemente preocupada com a manutenção da ordem social. Outro fator de relevo é que o Rei configura uma necessidade social de um "alguém" que sirva de fundamento à justiça e à ordem. Talvez por esse motivo é que a personagem da Filha, após ser seduzida por Dom Juan, ainda questione a existência de um "quien" que assegure aquele fundamento e que o deturpador da honra seja rendido.

Como se vê, muito nos interessa a missão dramática da figura do Rei, bem como as reivindicações da nobreza. Isso nos servirá de questionamento para a análise do processo de construção da personagem da Filha do Comendador. A propósito, para Aristóteles (2000, p. 105):

Há os que dizem que o homem feliz é necessariamente justo, enquanto para o vulgo é paradoxal que um rei não seja feliz. Induzir a paradoxos deste gênero corresponde a induzir na contrariedade da natureza e da lei, porque a lei é opinião do vulgo, e os sábios falam segundo a natureza, em obediência à verdade.

Assim, o Rei está predestinado a um dever moral e religioso para com seus súditos. Sua felicidade está condicionada, na maioria das vezes, pela missão moral que o cerca, ou mesmo pelo ofício sacro de representante de Deus na Terra, dentro do âmbito de seu reino. Estas características, unidas a uma política das aparências, tornam talvez necessário fazer ressaltar um tipo de sapiência que é comum aos "discretos" (sem esquecer que na camada dos súditos ocorre uma espécie de submissão, que se revela por meio de uma disposição hierárquica). No fundo, esse ponto envolve uma elucidação não 
apenas sobre o papel do Rei, mas também sobre outros elementos masculinos desse sistema de poder, como o Comendador, Dom Juan e o Marquês de la Mota. Tais reflexões servem para que tenhamos uma base à compreensão da atitude da Filha, a única personagem da peça que enfrenta os homens e que, assim, aproxima-se das características que são comuns aos varões da obra atribuída a Tirso de Molina.

Compreendemos que a representação da divindade, a reverência, a autoridade e a justiça não são os únicos sinais da importância do Rei dentro da ordem de valores que nele culmina. Apenas queremos descrever aqui como a disposição hierárquica das personagens expressa características semelhantes (é o caso, por exemplo, de Dom Gonzalo, Dona Ana, o Marquês e Dom Juan). Muito embora o Rei, há muito tempo, seja uma figura discutível em termos de representação ${ }^{17}$, abordaremos essa instigante figura como centro de um mascaramento da vida social, em prol dos interesses pessoais e dos privilégios que devem ser mantidos, como já dissemos, a qualquer preço. Assim, abordar a presença do monarca na trama equivale a evocar aos privilégios concedidos àqueles que são contemplados pelo poder de decisão e ainda venerados pela própria coletividade. Por isso, entre a nobreza era bem provável que um clima de desconfiança pairasse sobre os iguais, detentores de privilégios que os contrapunham. Nesse aspecto, Hansen alerta que a função do Rei não é apenas aquela que corresponde a uma imagem mitológica que fica gravada em cada súdito, mas é principalmente a de desempenhar um papel concreto no

\footnotetext{
${ }^{17}$ Apesar de discutirmos o mascaramento do monarca em prol dos privilégios que são concedidos entre os componentes de certa camada social, sabemos que, à figura do rei é atribuída a relevância da ordem divina devido ao fato deste regular o caos humano. Em outras palavras, como um elemento regulador de toda sociedade.
} 
exercício da monarquia absoluta ${ }^{18}$, isto é, superior a quaisquer nobres, por privilegiados que fossem.

\footnotetext{
${ }^{18}$ Entendemos por papel "concreto" do monarca - em certo sentido - o fato de que o Rei representa um cargo político e, por isso, usufrui dos privilégios que Ihe são reconhecidos pela coletividade. Porém, o monarca pode ser também compreendido à luz do conflito que se instaura pela imparcialidade de seus atos. Logo, a função social do Rei precisa ser mantida a qualquer preço, mesmo que seja representada no plano alegórico como um "emblema", ou seja, como um corpo sem alma que passa a ser movido pelos interesses materiais.
} 


\section{UMA EQUIVALÊNCIA ENTRE OS GÊNEROS}

Tendo em vista o exposto até o momento, podemos dizer que Dona Ana, em El Burlador de Sevilla, pode ser interpretada a partir de uma atitude que se choca com determinado perfil de mulher, ou seja, daquela que geralmente é tratada pelos homens como um "objeto". Dentro deste perfil, a personagem do sexo frágil é louvada pela apreciação de sua extrema beleza, sua nobreza e seu "preparo" para o casamento. No entanto, notamos que o aspecto "discreto" da Filha acaba por evidenciar uma situação de igualdade no poder de decisão entre homem e mulher pertencentes a uma mesma esfera social privilegiada.

\subsection{Em cena: o poder das decisões}

Após o ato de sedução da Duquesa Isabela, aparece-nos o Rei de Nápoles. Com uma vela na mão, posta em um candeeiro, o soberano protesta contra aquilo que, para um representante de Deus na Terra, corresponderia a um atentado contra a ordem social que se instaurava no palácio:

\footnotetext{
Rey

Esto en prudencia consiste. iAh de mi guarda! Prendé a este hombre ${ }^{19}$.
}

Ao sair de cena a Duquesa Isabela, vemos Dom Pedro Tenorio embaixador da Espanha - e um guarda que, primeiramente, reverbera a decisão do Rei de Nápoles a fim de se prender o intruso. Contudo, Dom Pedro passa a empregar vários imperativos que acabam por expressar sua posição

\footnotetext{
${ }^{19}$ Versos 24-26 (grifo do autor deste trabalho).
} 
social ao decidir em nome do Rei: "Prendedle 20", "Matadle 21", "Apartad"2", "os retirad $^{23 ", ~ " D i ~ q u i e ́ n ~ e r e s ~}{ }^{24 "}$. Após Dom Juan declarar tratar-se de seu sobrinho, notamos que Dom Pedro Tenorio continua empregando palavras de ordem, porém, não mais em nome do Rei. Agora sua atitude é tomada em nome do sobrinho que cometeu um "deslize"; desse modo, a personagem manipula a cena conforme a necessidade de se manter ou não a aparência. A moral em questão se instala nos preceitos de uma ordem que se restringe ao campo familiar. Portanto, esse poder de decisão - correspondente aos privilégios dos nobres, de que desfrutava também seu sobrinho - acaba sendo acobertado por uma solução imediata, derivada de uma relação muito semelhante à de um pai que censura ao filho. Tal censura não teria um intuito apenas de manutenção de valores éticos nas relações pai/filho ou tio/sobrinho. Nesse contexto, o tio traduziria a lógica de uma política centrada na preservação das aparências, a qual se volta para uma postura de manutenção da integridade de seus iguais ${ }^{25}$.

Retomaremos alguns exemplos de verbos que traduzem o poder de tomada de decisão do tio, ou seja, de Dom Pedro Tenorio em favor do sobrinho. Como vimos, suas palavras assumem uma pedagogia muito próxima daquela que é comum aos laços familiares. Tal estratégia é muito utilizada na resolução dos problemas que dizem respeito à ordem social, mantida vorazmente pela nobreza. Enfim, evidenciaremos a forma de tratamento que é geralmente aplicada a Dom Juan após suas seduções das mulheres nobres:

\footnotetext{
${ }^{20}$ Verso 37.

${ }^{21}$ Verso 41.

${ }^{22}$ Verso 46.

${ }^{23}$ Verso 47.

${ }^{24}$ Verso 57.

${ }^{25}$ Referimo-nos aos homens que compõem a nobreza e que detêm o poder de decisão. Percebemos tratar-se de um grupo cuja hierarquia interna se pautará pelas questões de ordem familiar. Enfim, resolvem-se os problemas de acordo com a experiência das relações familiares, logo, de pai para filho ou mesmo de tio para sobrinho.
} 
"Dime presto lo que ha sido", "iDesobediente, atrevido!", "No prosigas", "No digas más, calla, baste", "Mira qué quieres hacer", "Álzate y muestra valor", "Baja por ese balcón".

A decisão dos poderosos em El Burlador de Sevilla revela um mascaramento que se articula desde o convívio doméstico e que não demonstra sequer uma preocupação com valores substanciais da ordem social. A ordem aparente que é manipulada pela nobreza nos propõe a ideia de uma categoria social que acaba por reforçar a sacralização, aceita pelas camadas submissas. A discrição dos relacionamentos interpessoais requer que não se abale uma expectativa popular na nobreza, expectativa esta que se pretende manter, nem afetar a confiança depositada pelos súditos nos membros da aristocracia. Um bom exemplo - que coloca à mostra a preocupação só aparente da nobreza - pode ser traduzido nos seguintes versos, que se inserem no contexto da fala do personagem Dom Pedro Tenorio, ao discutir com o sobrinho sobre o ocorrido com a Duquesa Isabela:

\section{Don Pedro Tenorio}

(...)

iY estás su honor ofendiendo,

y en tan principal mujer!

Pero en aquesta ocasión

nos daña la dilación ${ }^{26}$.

Percebemos o quanto Dom Pedro se preocupa com a adoção de uma postura "discreta", que busca preservar a reputação dos nobres. Essa maneira de tratar a questão nos permite delinear um pensamento sobre 0

\footnotetext{
${ }^{26}$ Versos 96-100 (grifo do autor deste trabalho).
} 
contraste entre a relevância que é dada à condição feminina palaciana e o descaso mediante qualquer mulher pertencente às classes inferiores. No fundo, percebemos ainda o quanto a presença do sexo frágil retratada na peça estabelece sua predestinação a estar subordinada ao homem, dentro da escala social que Hansen menciona como sendo uma "alegoria na submissão". Isso também nos expressa a organização social no século XVII:

(...) o Rei não é apenas uma imagem mitológica gravada em cada súdito, mas exprime-se concretamente no aparelho da monarquia absoluta; Deus não é apenas sensível pelo coração, mas revela-se através de uma Igreja de uma ordem encarnada, a que delegou poderes absolutos. Amar a Deus consiste em aderir a tal ordem e as suas regras - com primado da verticalidade: Deus no Céu, Rei da Terra; reis sobre a terra, alegorias do divino; súditos por terra, alegorias na submissão (HANSEN, 1986, p. 99).

A presença da mulher na peça nos permite averiguar uma ideia de subalternidade do sexo feminino em relação ao homem, dentro dessa ordem. E esse é um fenômeno social que acaba por atingir não somente a nobreza, mas também os outros estamentos: Deus no Ceu, os reis sobre a Terra (como representantes da divindade) e os próprios súditos também sobre a Terra, mas cada qual no lugar que lhe compete. Logo, se de um lado a Duquesa Isabela, em sua condição de mulher principal - referência dada por Dom Pedro - estará submissa ao pai, ao Rei e a Deus; por outro, a fala da personagem Dom Pedro nos confere a ideia de que qualquer mulher da categoria dos súditos serviria aos anseios "necessários" que foram justificados por Dom Juan. O sedutor é um jovem que goza de excepcionais privilégios de classe, sendo ainda dotado de grande energia e capacidade de ação. É bom lembrar que, de acordo com o crítico literário lan Watt (1997), podemos associar a imagem do sedutor ao 
quase impensável desprezo não apenas pelos códigos da sociedade estabelecida, mas também por todos os seres humanos. Isso ocorre porque alguém como Dom Juan passa a viver somente para si mesmo, perdendo, dessa forma, o temor do castigo.

Entendemos que, nessa linha de raciocínio, a presença feminina expressa um dilema, que é enfatizado na peça. Dom Juan não deveria se envolver com a Duquesa, por ser esta uma mulher principal, que comprometeria sua reputação. Dessa maneira se acaba subestimando qualquer outra mulher que não fosse tida por principal. Portanto, com base em Forastiere (apud. PEDRAZA JIMÉNEZ e RODRÍGUEZ CÁCERES, 1995), salientamos que o papel de decisão do Rei aqui se reafirmava por meio da função social que era representada por seu embaixador, no caso, Dom Pedro Tenorio. Contudo, o veículo propulsor do desequilíbrio da ordem social se evidencia em função da figura feminina que, dentro dessa ordem, não deveria ser alguém principal, e sim alguém que na visão do representante do Rei não atuasse como uma ameaça à ordem social (ou seja, uma mulher qualquer, por exemplo, uma aldeã). Nesse sentido, compreendemos que:

(...) entre los actantes existe una situación inicial de equilibrio en la que la aldea está connotada de forma neutra respecto a la honra, en tanto que la corte lo está positivamente. La corte pierde esta marca positiva por la función negativa de la provocación de la deshonra; pero la recupera al final cuando de la misma corte (a través frecuentemente de la figura del rey) viene la sanción integradora que devuelve la marca positiva a un representante de la misma nobleza deshonradora, casi siempre el proprio monarca (Ibid., p. 91).

A sanção integradora que Dom Pedro retrata é a de acobertar o sobrinho, eximindo-o do delito. Evidentemente, a imagem negativa não deve emergir da nobreza, que detém o poder de decisão, o que explicaria o cinismo 
de Isabela e um posterior arrependimento oportuno, comum à sua condição de mulher e nobre. Compare-se, na escala da submissão, o contraste com a personagem Aminta ${ }^{27}$. Esta, ao integrar o grupo dos "súditos por terra", está sujeita ao pai e, futuramente, ao marido. Ao se tomar por base a igual sujeição da mulher da Corte, isso as equipararia. Porém, no caso da mulher aldeã, sua condição envolve uma inferioridade a mais: ela estaria destinada a realizar os caprichos dos nobres. Sendo assim, a condição de mulher qualquer representaria um aspecto ainda mais negativo, isto é, o de ser uma ameaça, embora às vezes tolerável, à ordem necessária ao equilíbrio da Corte (mesmo estando igualmente sujeita aos desígnios dos Reis e de Deus, como as mulheres nobres).

No tocante ao sexo, portanto, a mulher apresenta uma subalternidade muito clara em relação ao homem ${ }^{28}$. Todavia, é interessante notar uma vez mais a hierarquia, graças à qual a mulher nobre também é proposta estrategicamente pelo dramaturgo. Nesse aspecto, depara-se com uma duquesa, que obviamente pertence à nobreza, e que deve ser preservada pela condição de depositária da honra daqueles que detêm o poder de decisão. A personagem feminina se expressa, neste caso, em seu papel de mulher principal, caracterizado pela observância das reverências e satisfações devidas ao Rei e àqueles que junto a ele executam o poder, a fim de que vigore a ordem. No entanto, reiteramos que o contraste que se estabelece com

\footnotetext{
${ }^{27}$ Personagem seduzida por Dom Juan, uma camponesa que vive em Dos Hermanas e que acabara de se casar com Batricio, este de igual condição social. Tanto a pescadora Tisbea, seduzida em Tarragona por Dom Juan, quanto a camponesa Aminta, que também foi seduzida em Dos Hermanas, integram na peça a categoria dos súditos.

${ }^{28}$ Ainda que cinicamente possamos notar o quanto a Duquesa Isabella se humilha diante do Rei a ponto de proferir o seguinte: “¿Con qué ojos veré al Rey?" (Verso 179).
} 
qualquer mulher aponta para uma crítica às desordens sexuais da nobreza ou, mais especificamente, do sobrinho de Dom Pedro:

\author{
Don Juan \\ Tío y señor, \\ Mozo soy y mozo fuiste; \\ $Y$, pues que de amor supiste, \\ Tenga disculpa mi amor. \\ Y, pues a decir me obligas \\ La verdad, oye y diréla: \\ yo engañé y gocé a Isabela, \\ La duquesa ${ }^{29}$.
}

Desse modo, em relação ao ato de decidir dos homens, fica bem evidente que o mau uso do poder de decisão por meio da figura da Duquesa caracterizará sua inconstância, tanto por si mesma, em seu cinismo, quanto pela visão masculina que é proposta a seu respeito. Isabela não hesita em buscar um remendo de sua desgraça na menção que faz ao Duque Octavio, mesmo ao saber que ele não era o autor de sua desonra:

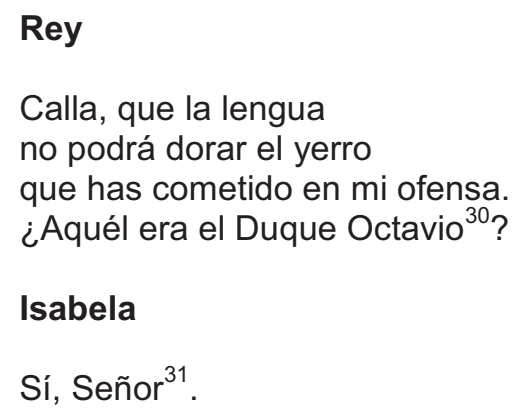

Vejamos agora, na fala do Rei, um exemplo da visão que subestima a presença da Duquesa:

\footnotetext{
${ }^{29}$ Versos 65-72.

${ }^{30}$ Versos 187-188.

${ }^{31}$ Verso 189.
} 


\section{Rey}

iAh, pobre honor! Si eres alma

del hombre, ¿por qué te dejan

en la mujer inconstante,

si es la misma ligereza ${ }^{32}$ ?

Neste caso notamos uma depreciação do papel da Duquesa perante a Corte. Podemos dizer que a maneira pela qual Isabela é subestimada pelos palacianos nos recorda a imagem que os gregos tinham a respeito da mulher. Tal imagem pode ser ilustrada através do termo misogynia, "misoginia" em português. Com isso, os gregos expressavam certo desprezo ou mesmo uma espécie de ódio pela mulher. Era comum um cidadão da Grécia Antiga se dedicar simultaneamente ao amor da esposa, da hetaira, espécie de amante, e de um efebo, isto é, um moço. Assim, não se ocultava da sociedade a situação de matrimônio, que se considerava compatível com mais dois componentes. Tampouco se desconhecia o que ocorria com o homem quando decidia estar nos braços da outra ou do outro.

Em termos históricos, essa tarefa de tomada de decisão sempre foi uma prerrogativa dos homens, fato que muito contribuiu para a ideia de misoginia. Na Idade Média, por exemplo, quando já era comum que a vida fosse regida sob o governo dos homens, nota-se a caracterização de uma sociedade fortemente marcada por pensamentos e atitudes misóginos, o que na maioria das vezes era sustentado pela cultura clerical dominante.

Após estabelecermos algumas notas da condição de Isabela, podemos dizer que nesta peça, como, aliás, desde a sociedade medieval, o papel e o espaço a ser ocupado pelas mulheres eram definidos previamente pelos homens: sua existência era determinada pelo controle masculino e ficavam

\footnotetext{
${ }^{32}$ Versos $171-174$
} 
sempre sob tutela dos homens. As esposas, as filhas e as sobrinhas se submetiam ao poder do marido, do pai, do irmão, do tio ou de qualquer outro homem que assumisse a responsabilidade sobre elas.

No palácio, diante do problema desencadeado pela atitude insensata de Isabela, o Rei de Nápoles questiona a inconstância feminina, que se espelha na Duquesa. Após indagar a função da mulher, que em tese seria a de complementar o homem, supõe-se que o sexo feminino vacila, ao valer-se da astúcia para que as aparências sejam mantidas. Trata-se de uma atribuição que é comum aos homens:

\author{
Rey \\ Don Pedro Tenorio, al punto \\ a esa mujer llevad presa \\ a una torre, y con secreto \\ haced que al Duque le prendan, \\ que quiero hacer que le cumplan \\ la palabra o la promesa ${ }^{33}$.
}

Será impossível que à Duquesa Isabela enfrente o Rei sem que lhe pese o seu malfeito. Na verdade, a personagem está enraizada ou mesmo presa pelo dramaturgo a uma condição adversa que pairou historicamente sobre o sexo frágil, a saber, as decisões cabem aos homens. Embora Isabela se reverencie e se humilhe ao suplicar que o monarca lhe direcione o rosto, sua tomada de decisão diante dos homens é frustrada. Tudo nos leva a crer que Isabela se entrega aos desígnios do poder masculino, manifestando uma

${ }^{33}$ Versos $195-200$ 
reivindicação contra seu estado de inércia apenas diante de uma igual, em termos de sexo ${ }^{34}$ :

\author{
Tisbea \\ Que me lleváis os ruego \\ con vos, señora, a mí y a un viejo padre, \\ porque de aqueste fuego \\ la venganza me dé que más me cuadre, \\ y al rey pida justicia \\ de este engaño y traición, de esta malicia. \\ $(\ldots)^{35}$ \\ Duquesa Isabela \\ Ven en mi compañía ${ }^{36}$. \\ Tisbea \\ iMal haya la mujer que en hombre fía ${ }^{37}$ !
}

\title{
2.2 O pai infiel e uma filha sem resistência
}

Como dissemos, o que diferencia e destaca Dona Ana de Ulloa das demais personagens femininas na peça é a forma como expressa suas vontades, seus desejos. Isto é o que a aproxima do modo de agir de uma figura masculina como, por exemplo, seu pai. Dom Gonzalo de Ulloa é o Comendador ou Commendatore, título que merece algum comentário. O termo é originário do italiano, e sugere à ideia de "comandante", relacionando-se a uma importante instituição cavalheiresca de origem medieval, a Ordem de Calatrava. Esta ordem militar foi fundada por São Raimundo, um monge que foi ajudado por Diogo Velasques, também religioso cisterciense. Seu objetivo era

\footnotetext{
${ }^{34}$ Muito embora elas pertençam a camadas sociais diferentes, a Duquesa Isabela impõe-se após sua subordinação às decisões masculinas, convidando Tisbea (pescadora) a proclamar sua reivindicação. Ambas almejam justiça mediante a expectativa que é nutrida pela ação do Rei.

${ }^{35}$ Versos 2293-2298.

${ }^{36}$ Verso 2303.

${ }^{37}$ Verso 2304.
} 
defender a cidade fronteiriça de Calatrava contra os ataques dos mouros, sendo essa ordem militar confirmada em 1164 pelo Papa Alexandre III. As origens da Ordem de Calatrava, como as das demais ordens militares, remontam, portanto, à Idade Média, no tempo das grandes cruzadas. Os feitos dos cruzados proporcionaram amplo pretexto dramático para a comédia, graças a um fenômeno comum na sociedade espanhola do século XII: o desejo de enobrecimento através das ordens militares.

Nesse contexto se situa a ilustre personagem do Comendador Dom Gonzalo de Ulloa, portadora da tarefa de relatar ao Rei de Castela os bons resultados que alcançava em sua missão a Portugal. A figura de Dom Gonzalo supõe a ideia de um servidor leal. Tal característica se evidencia quando o Rei de Castela, a fim de se remediar o delito de Dom Juan contra o Duque Octavio, decide que Dona Ana deve casar-se com o Duque, premiando Dom Gonzalo com um genro nobre. Trata-se de uma manipulação que fora articulada pelo soberano e ligada a uma política de ajustes da ordem. Assim, a personagem de Dona Ana de Ulloa é proposta diante de um dilema pelo qual,

(...) nos encontramos frente a unos papeles bien definidos, casi fijados en una fatalidad ineludible a la que sólo se sustrae la caprichosa personalidad de los personajes, modelados cada vez sobre su particular situación contingente (RICO, 1991, p. 471).

Tal dilema se estabelece por um motivo que acaba por favorecer a ação dramática da Filha do Comendador na trama. Primeiramente, a personagem de Dona Ana é proposta como uma pessoa que está amorosamente envolvida 
com o primo, o Marquês de la Mota. Além disso, é preciso considerar-se a inquietação que o ato de decidir de seu pai lhe provoca:

\author{
Dona Ana \\ Mi padre infiel \\ en secreto me ha casado \\ sin poderme resistir ${ }^{38}$.
}

É importante observar a maneira como a Filha qualifica o pai. Isso sintomaticamente acaba por estabelecer uma relação de causa e consequência, no tocante àquilo que Ihe deixa inquieta. Para Dona Ana, seu pai é infiel, e apesar disso ela mesma reconhece que não lhe pode resistir. Assim, vemo-nos diante de um fator muito relevante nessa figura feminina: o traço dilemático, pelo qual aquilo que ocorre contra sua vontade favorece o despertar de uma atitude. Tal postura não foi encontrada anteriormente na ação da Duquesa Isabela. Portanto, a função dramática de Dona Ana se revela pela impossibilidade de ação dentro da ordem estabelecida. $O$ espectador parece então a almejar da trama uma necessidade de mudança da situação feminina: desponta a ideia de uma possível "justiça poética", que tende a ser necessária para que o conflito seja amenizado. Essa impossibilidade de ação da Filha é capaz de mover seu personagem dramaticamente, mediante a decisão tomada pelo pai. Na mudança de si própria, por uma espécie de agonia consigo mesma (a partir de uma situação-limite de resistência) verificase a causa de sua reação social. Encontrando-se em uma situação de desespero, Dona Ana decide convidar seu primo para que a visite à noite. Se por um lado sua ação, conforme ressalta Varey (op. cit., p. 148), é considerada

\footnotetext{
${ }^{38}$ Versos $1361-1363$ (grifo do autor deste trabalho).
} 
como uma imprudência ${ }^{39}$; por outro, demonstra uma atitude "discreta" da Filha ao tomar uma decisão ${ }^{40}$.

O choque entre a expectativa do pai - enquanto servidor leal ao Rei - e o poder de decisão assumido pela Filha, que se mostra inquieta e manipulada pelos homens, é o que conduz a cena para uma consequência inevitável: a ação de Ana de Ulloa. Por exemplo, quando o Rei diz ao Comendador que havia decidido oferecer a mão de sua filha a um cavaleiro de sua predileção, Dom Gonzalo aceita de imediato: somente depois é que pergunta se poderia saber o nome do rapaz escolhido. Esse acontecimento causa uma situação conflituosa para a Filha - por ela não concordar em ser apenas um "objeto"mas demonstra o quanto a fé no Rei era para o Comendador de necessidade absoluta, indissociável de um completo e virtuoso fidalgo. O reconhecimento dessa necessidade talvez justifique o fato de ser ele o escolhido por Deus para servir de instrumento de sua ação misericordiosa ${ }^{41}$. Logo, o dramaturgo recorre ao fator sobrenatural como único meio de barrar os elementos que comprometiam a ordem social e mesmo a coerência da obra em si, para que a trama fosse poeticamente justa. Sendo assim, o Comendador, no intuito de

\footnotetext{
${ }^{39}$ Cabe afirmar que na representação seiscentista do "discreto", a prudência é a virtude política principal, pois é ela que, pelo cálculo da aparência adequada, consegue evitar a murmuração da opinião, quando aplica um decoro específico da circunstância. A esse respeito, cf. HANSEN, João A. O Discreto. In: NOVAES, A. (org.). Libertinos e libertários. São Paulo: MINC/FUNARTE/ Companhia das Letras, 1996, p. 96.

${ }^{40}$ Quer dizer, trata-se de uma atitude comum aos homens. Nesse contexto, aplicamos o conceito de discrição que fora desenvolvido em nosso trabalho. Para a nobreza, a necessidade de se manter as aparências em prol da honra, bem como de "emendar" algum deslize que prejudique a reputação de sua classe caracterizava uma atitude comum. Para Dona Ana, podemos dizer que sua proposta visaria ao mesmo. Isso porque diante de uma situação feminina que se the revela adversa, ela reage de maneira ousada, enquanto personagem feminina, para a época (como vimos, historicamente submissa ao sexo masculino) e cobiça o encontro com o amante.

${ }^{41}$ Segundo SHEPARD (op. cit., p.86), Aristóteles faz referência a um tipo de desabafo emocional que deriva de uma espécie de excitação da misericórdia e do medo. Com isso, criase um efeito estético único: a Filha acaba por sustentar uma corrente moralizante na trama, que conduzirá à kátharsis. Nesse sentido, Giraldi Cintio assevera que a tragédia é capaz de limpar a mente do vício mediante a piedade e o temor, alcançando sua finalidade moral.
} 
defender a honra da Filha, é assassinado no momento em que desempenha a tarefa primordial dos pais, o que se revela comum nas peças do teatro espanhol. A defesa da honra feminina em um ambiente fechado e sua profusão de elementos intrigantes era o tema favorito dos dramas na Espanha. Como foi mencionado anteriormente, atribuía-se às mulheres o papel de depositárias da honra dos homens, ou seja, a responsabilidade do pai pela honra da filha era um dado vital para a reputação da família como um todo.

\subsection{A Filha do Comendador e as decisões masculinas}

Nesse ponto, será oportuno comparar as atitudes femininas diante dos homens, com relação às personagens Dona Ana e Duquesa Isabela. Verificamos que ambas convidam seus amantes para visitá-las à noite, e as duas são integrantes de uma parte privilegiada da sociedade espanhola, posto que "entre vulgares a maior discrição é o fingimento da sua falta" ${ }^{42}$. Porém, devemos notar que não há nenhum empecilho ao matrimônio de Isabela com o Duque Octavio. O convite de Isabela não pode ser ocultado. Já no caso de Dona Ana, a condição adversa e sua discrição Ihe favoreceram ocultar seu convite amoroso, embora lhe fosse impossível perdoar a decisão da qual ela foi vítima. Isso por ter sido colocada em uma situação falsa, por meio da precipitada promessa do Rei de Castela de dar sua mão ao Duque Octavio, sem antes saber se ela tinha alguma predileção ${ }^{43}$. Este fato a diferencia de Isabela, inclusive pela ausência de um castigo severo. Cabe ainda dizer que a

\footnotetext{
${ }^{42}$ Cf. HANSEN (1996, p. 97), entenda-se "vulgar" como sendo o indivíduo que se insere na mesma situação social, portanto "igual". Vale ainda lembrar que ambas depositam confiança nos homens em relação à responsabilidade que assumirão por sua tomada de decisão.

${ }^{43}$ Parece-nos que ter predileção é um fator importante para a personagem feminina. No caso de Dona Ana, isso faz com que ela tome uma atitude que caracteriza uma opção de escolha, o que também a equipara aos homens em suas atitudes típicas.
} 
Filha do Comendador é a única, entre as mulheres requeridas por Dom Juan, que não é seduzida fisicamente. Ela não o cobiçou, portanto não "quis" que isso ocorresse:

\section{Don Juan}

Que me abraso, no me aprietes.

Con la daga he de matarte, mas, iay!, que me canso en vano de tirar golpes al aire.

A tu hija no ofendí, que vio mis engaños antes ${ }^{44}$.

Assim, notamos que há um reconhecimento das personagens masculinas no que compete às ações da Filha. No tocante ao reconhecimento de uma ação, Aristóteles e Pinciano alertam, de maneira semelhante, sobre aquilo que se pretende no contexto da peça teatral:

(...) que el espectador de una tragedia reconozca en el trágico destino del protagonista una similitud con las posibilidades de la vida real, y sienta aminorarse sus propios padecimientos al comprender que semejantes cosas son la propiedad común de la humanidad entera. En el mejor de los casos, sin embargo, Pinciano sólo tiene una ligera idea del significado del original griego. Kátharsis, pues, tiene, para Pinciano, la útil función de hacer mejores los hombres (SHEPARD, 1970, p. 87).

O comportamento cênico de Dona Ana lhe confere superioridade em relação às demais mulheres, inclusive quanto às expectativas dos homens. Isso é capaz de reafirmar os traços de uma atitude voluntariosa e caprichosa, como aponta Rico (op. cit.).

\footnotetext{
${ }^{44}$ Versos 2898-2903.
} 
Vale ainda lembrar que Dona Ana é a única personagem de El Burlador de Sevilla cujo ato de "querer" ultrapassa os limites de sua condição de filha e, portanto, submissa. Suas ambições são reconhecidas pelo próprio Rei, posto que ela sempre expressa suas vontades diante dos homens ${ }^{45}$ :

\author{
Rey \\ No es bien que el Duque Octavio \\ sea el restaurador de aqueste agravio. \\ Doña Ana, con la Reina, me ha pedido \\ que perdone al Marqués, porque Doña Ana, \\ ya que el padre murió, quiere marido, \\ porque si le perdió, con él le gana. \\ Iréis con poca gente, y sin ruido \\ luego, a hablarle a la fuerza de Triana. \\ Por su satisfacción, y por abono \\ de su agraviada prima, le perdono ${ }^{46}$.
}

Podemos dizer que a cena de Dona Ana segue o ditame que é peculiar à comédia. Nesta, articula-se um estado de calma e harmonia, introduzindo-se em seguida a desordem, mas ao final se restabelecendo o equilíbrio, isto é, a ordem. Na obra em análise, isso ocorre devido à presença de um elemento perturbador, o amor. Assim, estar solteiro é um estado de equilíbrio que se corrompe através das relações pré-matrimoniais. Nesse aspecto, espera-se que a autoridade do monarca estabeleça a justiça de acordo com a expectativa social.

Dom Juan visa ao poder em suas relações só aparentemente amorosas. Com isso, ele acaba por sacrificar as mulheres em prol de sua glória. Essa

\footnotetext{
${ }^{45}$ Dona Ana de Ulloa é uma personagem de referência na peça. Mesmo representando uma filha de comendador e estando suas vontades condicionadas às decisões do pai, essa figura feminina expressa uma atitude: o poder de decisão pelo encontro com o primo. Assim, após a morte do pai, ela é reconhecida pelo Rei, pois a Filha do Comendador almeja um marido. Sendo assim, a aparição de Dona Ana acaba por articular a ação dramática de Dom Juan e das demais personagens rumo a um desfecho de fundo moralizante.

${ }^{46}$ Versos 2604-2613 (grifo do autor deste trabalho).
} 
característica que é típica dos homens: a glória de dominar está somada ao poder de decisão. Dom Juan abusa de tal modo desse poder que acaba por romper impunemente as leis seculares dos homens durante a efemeridade de seu tempo terreno. Dessa maneira, para que se restabeleça a ordem, ele terá de sofrer por toda a eternidade a condenação. Isto é o que exigia a doutrina vigente, ou seja, o pensamento da Contra Reforma.

\section{4 "Querer é poder” no tocante ao sexo}

Podemos dizer que as falas das personagens que foram tratadas anteriormente, independentemente do sexo, expressam a ideia de um poder de decisão que é empregado pelos componentes da nobreza de El Burlador de Sevilla. Na tomada de decisão, como já vimos, deparamo-nos com circunstâncias históricas que são favoráveis aos homens e que são condicionantes de um processo de subalternidade da situação da mulher, mesmo quando esta se insere em uma esfera privilegiada da sociedade. Assim, segundo Aristóteles:

Quando se alinham falas pelas quais se revelam caracteres, mesmo que bem construídas em relação a linguagem e ideias, nem por isso ter-se-á realizado obra trágica; muito mais o conseguirá a tragédia que melhor se servir desses meios, mas também provida de narrativa e de trama. Ademais, os principais meios pelos quais a tragédia fascina as platéias fazem parte da fábula, ou seja, as peripécias e os reconhecimentos. Também se mostra a superioridade do enredo no fato de que se conseguem melhores efeitos na fala e nos caracteres, mais do que na ordenação das ações. É o que se percebe em quase todos os autores primitivos (ARISTÓTELES, 2000, p. 44).

Em suma, o reconhecimento das personagens masculinas é capaz de revelar-nos uma aparente misoginia em relação à mulher. Provavelmente, a 
frustração da Duquesa Isabella configura sua atitude cínica. Contudo, entendemos que a caprichosa Dona Ana ganha uma relevância sintomática, ou seja, a condição submissa perante a autoridade do sexo masculino pode ser mudada pelas mulheres. Assim, enquanto a Duquesa Isabela se humilhava diante dos homens governantes, Dona Ana, sem se humilhar, aponta as falhas em seu sedutor e requisita uma providência por parte dos administradores da justiça acerca do atentado contra a honra. Ao final, parece-nos que a personagem almeja a eliminação daquele que coloca em prova a ordem social:

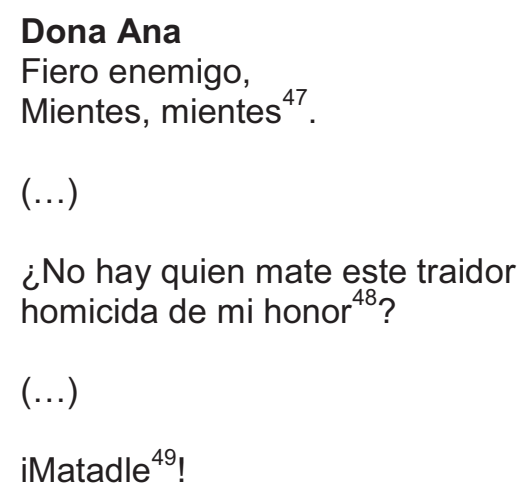

Surpreendentemente, Dona Ana revela sua participação no sistema inspirado pelo decoro, preservando, dentro da ordem social a que pertence, o fundamento do código de honra, que era um dos pontos centrais dessa ordem. Então é que procede como os homens, ao se alinhar a este perfil de defesa do decoro, que já era comum à nobreza. Tanto assim que, em cena anterior, Don Pedro utiliza o mesmo verso "iMatadle ${ }^{50}$ !, ao se referir a Don Juan. Portanto, a diferença entre Isabela e Ana é que, enquanto a primeira se humilha e não enfrenta os homens, a segunda, ao fingir, cobiça a realização de sua vontade,

\footnotetext{
${ }^{47}$ Versos 1609-1610.

${ }^{48}$ Versos $1610-1611$.

${ }^{49}$ Verso 1616.

${ }^{50}$ Verso 41.
} 
mas o faz mantendo as aparências de Filha guardiã da honra. Desse modo, reiteramos que o poder de decisão por ela assumido diante dos homens poderia estar associado à inquietação gerada por sua impossibilidade de resistência às decisões de seu pai e do Rei de Castela.

Esse aspecto, centrado no poder de decisão assumido aqui pela Filha do Comendador, revela-se substancial na comédia. Se de um lado, a trama pretende elucidar os ideais de uma sociedade - na qual a manutenção das aparências se sobrepõe às cobiças humanas - por outro lado, o dramaturgo faz ressaltar a personagem da Filha Comendador, ao por em cena um comportamento feminino que tende ao irreverente. $\mathrm{Na}$ medida em que isso ocorre, Dona Ana adquire alguns traços que são comuns ao tema do "mundo al revés", onde é a mulher "la que lleva a la cintura la espada, y el hombre la rueca" ${ }^{51}$.

Assim, no que tange à condição feminina especificamente, observamos ainda uma vez que se torna evidente a subalternidade das mulheres em uma sociedade patriarcal, ou seja, completamente dominada pelos homens. Haja vista o diálogo travado entre o Comendador e o Rei de Castela:

Rey

Pues os la quiero casar de mi mano.

\section{Don Gonzalo}

Como sea

Tu gusto, digo, señor,

Que yo lo acepto por ella;

Pero, ¿quién es el esposo? ${ }^{52}$

\footnotetext{
${ }^{51}$ DOLFI, Laura, VAREY, Jonh E. La mujer en Tirso: Don Gil de las calzas verdes. Apud RICO, Francisco (org.). Op. cit., p.472.

${ }^{52}$ Versos 910-915.
} 
Logo, essa ação de desejar e realizar uma vontade e, consequentemente, de tomar decisões, atitude comum entre os homens, permite-nos aludir a algumas mulheres que experimentavam o desejo, em um sentido amplo, de cobiçar o que Ihes era necessário e, para tanto, tomavam suas decisões. Personalidades assim já se encontram na Antiguidade Clássica. Possivelmente, uma personagem feminina grega que sintetiza o tema da máxima "querer é poder", e que mostra analogia com a atitude da Filha do Comendador, é a figura de Antígona. Ela aparece na trilogia tebana, de Sófocles.

Na segunda peça, Édipo em Colono e após a tragédia de seu pai Édipo, que furou os próprios olhos ao descobrir que havia matado o pai e se casado com a mãe, Antígona, ampara-o em uma vida errante até a cidade de Colono. Como Dona Ana, tratava-se também de uma donzela da aristocracia no limite de suas forças. Então, a filha agasalha o pai, alimenta-o e o socorre com afeto, conduzindo-o até a cidade onde a figura paterna encontra uma morte gloriosa e misteriosa, sendo transposto pelos deuses a um plano superior. Antígona desejou um resto de vida e uma morte digna para o pai e o conseguiu.

Já a terceira peça da trilogia mostra algo de muito semelhante ao poder de decisão da Filha confinada a uma hierarquia masculina. Antígona enfrenta as leis do Estado de Tebas e os decretos do Rei Creonte, que havia proibido que seu irmão Polinices ${ }^{53}$ fosse enterrado. Logo, Antígona deseja dar um enterro digno ao irmão. Para tanto, a personagem feminina coloca os direitos da família e o respeito à dignidade dos mortos acima das leis do Estado ${ }^{54}$.

\footnotetext{
${ }^{53}$ Polinices, segundo a mitologia, havia se rebelado contra Tebas e armado um exército para combater a cidade, sendo morto por seu outro irmão Etéocles, que também morre no conflito.

${ }^{54}$ Esse feito de Antígona nos chama a atenção no sentido de que Dona Ana também coloca seu desejo de se encontrar com o primo (que ela realmente amava) acima dos direitos da
} 
Enfrentando todo o aparato estatal (o Rei Creonte e toda a sociedade tebana), sua ação faz desencadear o processo trágico ${ }^{55}$. Desfaz o casamento que teria com Hemon, filho de Creonte, o que leva o rapaz ao suicídio. Posteriormente a filha e Creonte também são destruídos, mas no fim Antígona realiza o seu desejo e dá um enterro digno a Polinices.

Outra figura que também poderia ser tomada como exemplo da atuação feminina na Antiguidade Clássica, pela postura reivindicatória, é a de Medéia, da tragédia homônima de Eurípides. Em linhas gerais, essa personagem se associaria a Ana de Ulloa pela rebeldia que é representada contra a autoridade paterna, ou seja, por não poder resistir ao pai infiel. Eis a fala da famosa personagem após ter sido preterida por seu marido Jasão:

De todos os seres que respiram e que pensam, nós outras, as mulheres, somos as mais miseráveis. Precisamos primeiro comprar muito caro um marido, para depois termos nele um senhor absoluto de nossa pessoa, segundo flagelo ainda pior que o primeiro. (...) $\mathrm{O}$ homem, dono do lar, sai para distrair-se de seu tédio junto de algum amigo ou de pessoas de sua idade; mas nós, é preciso não termos olhos a não ser para ele. Dizem que levamos em nossas casas uma vida isenta de perigos, ao passo que eles combatem com a arma na mão; é falso. Eu preferiria tomar parte em três combates a dar à luz uma só vez (EURÍPIDES, 1976, p. 171)

Notamos, assim, que a falta de liberdade é uma característica marcante e antiga das mulheres do meio aristocrático. Destituídas de toda autonomia e liberdade de movimento, elas viviam encerradas no interior de seus lares e de seus quartos. Ao se deslocarem, praticavam tal feito sob condições

família e, consequentemente, acima das leis do Estado e, portanto, de Deus (já que o rei era considerado o representante de Deus na Terra).

${ }^{55} \mathrm{O}$ processo trágico, desencadeado por Antígona, pode também estar associado à presença do pai de Dona Ana (o Comendador Dom Gonzalo de Ulloa). Com a morte deste, será estabelecido um movimento rumo ao trágico, que conduzirá El Burlador de Sevilla a um fim poeticamente justo, para que se viabilize o restabelecimento da ordem social. 
específicas: escoltadas pelo marido, pelo pai ou irmão. Ou ainda, quando subestimavam a vigilância masculina, almejavam seus feitos por meio de artimanhas "traiçoeiras".

Portanto, em nossa visão, a vida da mulher - em muitas ocasiões parecia estar restrita ao espaço doméstico. Assim, as mulheres da aristocracia se dedicariam a maior parte do tempo ao cuidado com a família, à organização da casa, à tecelagem, à alimentação e à educação dos filhos pequenos, responsabilidades que compartilhavam com as criadas.

Desse modo, notamos que a reputação de Dona Ana não se abala como a da Duquesa Isabella. Contrariamente ao que se esperava acerca da condição submissa da mulher, deparamo-nos, no caso da primeira, com uma atitude feminina que supera o tradicionalismo corrompido por Isabela, postura que custa tão caro à nobreza. Conforme Hansen (1991, p. 91), "quando discretos se atacam uns aos outros, atribuem desonra às mulheres".

A par disso, encontraremos em Dona Ana uma feição "varonil" responsável por impulsionar essa personagem. Ou seja, a Filha enfrenta aos homens com uma postura de equivalência entre os gêneros e ainda conquista o reconhecimento de suas ações diante dos homens:

\section{Rey}

No es bien que el Duque Octavio sea el restaurador de aqueste agravio ${ }^{56}$. (...)

\section{Don Juan}

$(\ldots)$

A tu hija no ofendí, que vio mis engaños antes ${ }^{57}$.

\footnotetext{
${ }^{56}$ Versos 2604-2605.

${ }^{57}$ Versos 2902-2903 (grifo do autor deste trabalho).
} 
Assim, podemos dizer que as cenas de reconhecimento dos agentes masculinos na peça são capazes de revelar ao espectador fundamentos de moralidade, isso feito a partir de uma personagem feminina cujas ações podem ser concebidas de maneira heróica se tomamos por referência os nobres que articulam o poder na Corte, no caso, os homens.

No tocante ao sexo masculino, se tivermos em conta o poder de se tomar uma decisão, é bem oportuna a comparação de Dom Juan e do Marquês de la Mota com os grandes homens que foram dominados pelos próprios egos, como por exemplo, Sócrates e Júlio César.

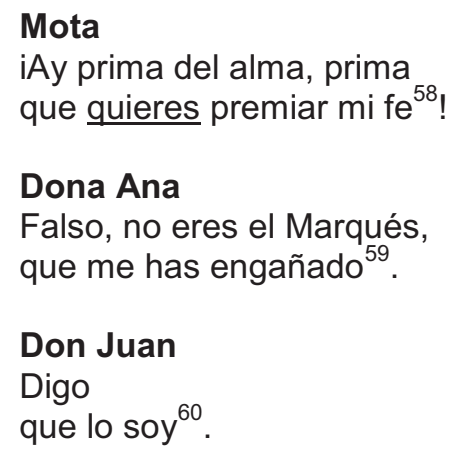

Assim como Sócrates e Julio César, os dois fidalgos são individualistas por excelência e donos de uma identidade que os marcou historicamente, fazendo suas escolhas com inteira liberdade, a fim de almejarem seus objetivos. No entanto, o fato de ambos levarem suas vidas de modo a não se deixarem afetar pelo código de honra vigente é o que os faz adotar uma atitude ego contra mundum na peça:

\footnotetext{
${ }^{58}$ Versos $1454-1455$ (grifo do autor deste trabalho).

${ }^{59}$ Versos 1605.

${ }^{60}$ Versos 1606.
} 
El individuo no es dueño de desprenderse de posesiones tan engorrosas como puedan ser una hija, hermana o mujer más o menos propensa a los amoríos, o solicitada no había de consentírselo (PEDRAZA JIMÉNEZ e RODRÍGUEZ CÁCERES, 1995, p. 89).

Como se verifica, os homens não se deixam afetar pelas normas e acabam por estabelecer uma espécie de ponte entre eles e as realidades sociais e intelectuais que os cercam.

No que diz respeito ao poder, é bem provável que uma situação privilegiada socialmente favoreça de alguma maneira o indivíduo, tanto na possibilidade de expor quanto na de fazer valer uma vontade. Este é o caso de Dona Ana de Ulloa ao assumir uma atitude viril diante os homens. 


\section{A REPRESENTAÇÃO DA FILHA COMO PERSONAGEM NECESSÁRIA}

Como foi proposto no capítulo anterior, Dona Ana é uma personagem que leva consigo os traços que caracterizam uma ação. Esta que pode ser concebida na perspectiva de uma atitude equivalente à dos homens que são representados na comédia. Contudo, verificamos que a mostra de discrição da personagem da Filha pode ser lida como característica associada a uma expressão de vontade própria, que somente aqueles que detêm o poder seriam capazes de desfrutar. A comédia nos coloca, portanto, diante da representação do "querer" e do "poder", representação que culminará ao se desencadear o conceito de dupla justiça, relevante na peça: (i) a justiça dos homens, posta nas mãos do Rei e reafirmada pela atuação do Comendador e (ii) a justiça de Deus, que acaba por sugerir um ideal de liberdade católico, personificado pelo Convidado de Pedra. Assim, neste capítulo, trataremos de expor como as ações da Filha do Comendador ante as personagens masculinas são caracterizadas pelos preceitos dramáticos que ora preconizam uma ideia de justiça terrena, ora transpõem a realidade acerca de uma justiça divina. Para tanto, também exporemos algumas consequências baseadas nessas prerrogativas, como, por exemplo, o teatro dentro do próprio teatro e, ao fim, a interpretação de uma "discreta" aleivosia em cena no teatro clássico espanhol.

\subsection{Dona Ana e a justiça dos homens}

Dona Ana de Ulloa, ao assumir uma atitude comum aos homens que a cercam - ou seja, reage mediante o dilema de estar condicionada pelas ações masculinas - também carrega consigo um modo de agir discreto que muito nos 
lembra a ação política mascarada pelo "moralmente correto". Assim, como é sabido, a Filha do Comendador toma sua decisão ao convidar o Marquês de la Mota para um encontro amoroso em sua casa. Nesse sentido, podemos considerar esse perfil de personagem feminina como figura-chave para o desenvolvimento e o desfecho da trama.

A propósito, a presença de uma figura-chave na trama nos faz retomar a discussão inicial sobre os três modos de caracterização da personagem: através de suas ações, no que diz de si mesma e no que os outros dizem a seu respeito. Em função disso, Décio de Almeida Prado (op. cit., p. 91) acrescenta - como já mencionado no início deste trabalho - que a personagem eficaz é aquela que nos transmite sua natureza por meio de suas ações ${ }^{61}$. Nesse sentido, o crítico brasileiro está em conformidade com Aristóteles.

Dona Ana de Ulloa, sendo uma personagem marcada por uma atitude, torna-se muito eficaz na construção do enredo. A ação dramática é conduzida pela necessidade de uma presença sine qua non, assegurada por aquela personagem feminina que vem de "fora", ou seja, da cidade de Lisboa, mantendo em si uma imagem de pessoa conservadora que é peculiar ao local de origem. A tradição conservadora dessa origem é notada pelo pai, ao reafirmar ao Rei de Castela o elogio a esse memorável locus de morada de

\footnotetext{
${ }^{61}$ Décio de Almeida Prado inclusive associa a ação ao drama, o que é sustentado pelo sentido que é dado pelos gregos ao termo "drama": "Drama, em grego, significa etimologicamente ação: se quisermos delinear dramaticamente a personagem devemos ater-nos, pois, à esfera do comportamento, à psicologia extrospectiva e não introspectiva. Assim, no tocante à ação, o crítico está em consonância com Aristóteles. Para este, seria possível haver tragédia sem caracteres, mas não poderia havê-la sem ação, pois, por melhores que sejam as elocuções e os pensamentos, nem por isso tais elementos lograrão algum efeito sobre a plateia. Outro ponto interessante é que em momentos distintos da história do teatro existiram formas que não privilegiavam o enredo sobre os caracteres, sendo o enredo consequência da índole das personagens. Nesse aspecto, Rosenfeld aponta que é sempre possível perceber no teatro uma tendência a enfatizar a ação ou outra a valorizar a índole das personagens. Interessante notar que o crítico cita como exemplo o teatro de Ibsen, classificando-o como "drama analítico", em que "a ação nada é senão a própria análise dos personagens e da situação." Cf. ROSENFELD, Anatol. O Teatro Épico. São Paulo: Perspectiva, 2004, p. 85-90.
} 
dinastias cristãs, "donde los Reyes y reinas/ Católicos y Cristianos/ tienen sus casas perpetuas $^{62 "}$. Este elogio provavelmente corresponderia a uma espécie de adulação ao fundamento católico, em que o Rei se espelha para a conservação da ordem social. O incidente da morte do pai de Dona Ana, no entanto, pode ser concebido como um ato capaz de delinear o desfecho da trama. Isto é possível graças à atenção que o dramaturgo requer do espectador em relação à importância da autoridade paterna, dada por meio da figura de Dom Gonzalo de Ulloa:

Resulta sintomático que el único padre realmente funcional de las cuatro burladas sea Gonzalo de Ulloa, y que el matrimonio de Doña Ana, esencial en la cadena dramática que conduce a la muerte de Don Gonzalo, le sea dictado por el Rey al propio Comendador. En el momento en que éste muere, asume la función paterna que nadie es capaz de asumir: la de castigar al perturbador (MOLINA, 2005, p. 88).

Devemos observar que o pretexto do casamento, na tentativa de "ajuste" de uma falha causada por Dom Juan, acaba por destacar a Filha do Comendador como elemento essencial para o desenvolvimento de uma ação dramática de cunho moralizante. Isso porque, no caso do pai de Aminta, este se deixa levar pelo sonho de que o contato com Dom Juan Ihe seria favorável para uma aproximação com a nobreza. Já o pai de Tisbea nem aparece em cena. Dessa maneira, Dom Gonzalo assume a função de transmitir a ordem do Rei, já que Dom Juan nos é apresentado como um indivíduo que possui uma filiação duplicada:

${ }^{62}$ Versos 791-793. 
Con el fin de suscitar placer en el auditorio se recomienda hablar con dobles sentidos para lograr una cierta complicidad con el receptor, y también jugar con la incertidumbre y la verdad solapada, acudiendo a casos de honra y "acciones virtuosas" (LOPE DE VEGA, 2006, p. 50$51)$.

De um lado está seu tio, simbolicamente Rei de Nápoles; de outro, seu pai e o Rei de Castela. Enquanto o primeiro facilita a fuga, em Nápoles, a fim de que Dom Juan escape ao castigo, o segundo se confessa incapaz de "reformar" seu filho.

Ademais, não se pode esquecer que, de acordo com Jean Rousset, o ponto de articulação entre a Filha e a autoridade paterna ${ }^{63}$, que é referido na peça, acaba por favorecer o enredo e não os caracteres, pois as personagens se mobilizam por um objetivo moralizador que norteia toda a trama. Nesse caso, a personagem de Dona Ana elucida, por meio de sua atitude, a maneira como atuam os nobres, tanto no que corresponde à condição social quanto no que corresponde ao modo de os homens exercerem a autoridade.

Como ilustrou Aristóteles, o drama é imitação das ações humanas. Isso remete a uma correspondência com os feitos humanos, sendo este ponto inclusive mais importante que a descrição dos sentimentos que serão revelados por essas ditas ações (ESCRIBANO e MAYO, 1972, p. 42). Desse

\footnotetext{
${ }^{63}$ ROUSSET, Jean (org.). O Mito de Don Juan. Lisboa: Vega Universidade, [s.d.], p. 7-26. Para Rousset, os pais não são propriamente pais. A referência a eles ilustra seu papel como instância simbólica em El Burlador de Sevilla. Isso remete à maneira como a peça articula a crise da autoridade paterna e os mecanismos pelos quais o sistema político vigente se encontra nas mãos de uma camada privilegiada, detentora do poder de decisão ao subordinar a autoridade paterna a seus interesses. Cabe ressaltar que tal autoridade é empregada pelo dramaturgo como pretexto para reestruturação da ordem social que é "confiada" às mãos de Dom Gonzalo de Ulloa como Convidado de Pedra. Outro fator a se levar em consideração é o fato de ficar claro um questionamento ao próprio papel do Rei, que é articulado pelo dramaturgo. Se o Rei é o representante de Deus na Terra, seria mais conveniente a presença de um rei cujas atitudes fossem suficientes para a solução dos problemas terrenos, ou mesmo de um Rei na condição de Convidado de Pedra.
} 
modo, a atitude discreta da Filha do Comendador adere à crise do espírito humano, cuja raiz remonta aos acontecimentos históricos que atormentam o homem, entre o fim do século XVI e o início do XVII.

Se adotarmos Platão como referência, verificaremos que ele concebia a base para a ação política - que inclui qualquer ação - como sendo pautada na investigação científica e racional. Na Academia, fundada em 387 a.C., o filósofo mostrava a seus discípulos que a atividade humana, desde que pretendesse ser correta e responsável, não poderia ser norteada por valores instáveis, formulados segundo o relativismo e a diversidade das opiniões. Com base nisso, ao transpormos nossas atenções para o contexto da ação de cunho político retratada em El Burlador de Sevilla, percebemos que não apenas o "discreto" comportamento dos homens impera, mas também o das duas mulheres que compõem a esfera privilegiada. De um lado está Isabela, uma duquesa marcada pela instabilidade em relação a suas próprias atitudes, capaz de reafirmar uma política de aparências, que é articulada por Dom Pedro Tenorio e o Rei de Nápoles. De outro lado está Ana de Ulloa, Filha de Comendador, cujas vontades não coincidem com a postura social vigente. Por isso, Ana demonstra claramente sua constância ao convidar o Marquês para um encontro amoroso. Isso traduz sua insatisfação em relação às decisões do Rei e de seu pai.

Tais atitudes nos alertam para a falta de integração de uma nobreza "discreta" e corrupta ${ }^{64}$. Basta que se observe o clima de instabilidade que

\footnotetext{
${ }^{64}$ Os nobres que detém o poder se enganam e são enganados em prol das aparências. As mulheres apontam para uma atitude de decidir que é comum à nobreza. Se de um lado Isabela representa um princípio de conservação da ideia que se tinha da mulher como submissa e imprudente, por outro, Ana de Ulloa, além decidir tal como os homens, atua de maneira mais igualitária ao defender a honra, provocando o reconhecimento de sua "heróica" atitude feminina, que contraria a visão imprudente sugerida pela Duquesa.
} 
pairava sob Felipe III. Isso porque seu reinado não ofereceria aos espanhóis a segurança que acreditavam ter com Felipe II.

Como uma técnica da imagem retoricamente regrada, a discrição seiscentista prevê os excessos aparentes que hoje qualificamos como "libertinagem", principalmente quando se trata do erotismo, mas todo excesso, no caso, é produzido como representação distintiva do privilégio de uma posição superior na hierarquia e que é ordenada segundo os esquemas da racionalidade de corte absolutista (HANSEN, 1986, p. 79).

Essa postura de "adequação" a um código de honra se detém nas aparências de um jogo, para que os privilégios de uma posição superior na hierarquia sejam mantidos, tal como apresentada em El Burlador de Sevilla. Esta é a atitude levada a cabo pela personagem da Filha do Comendador, em sua discrição, ao cobiçar a satisfação de sua vontade. Isto se associa àquilo que Hansen aponta como sendo um "emblema" (Ibid., p. 96-98). Este termo ${ }^{65}$, segundo o crítico (Id. 1991, p. 96), pode ser concebido na perspectiva de um corpo sem alma e se refere apenas à imagem do efeito que se pretende representar em uma determinada situação. Por exemplo, uma Tocha incendiada, que em posição inclinada melhor se acende e resplandece, significa a Humildade ou a Virtude ${ }^{66}$. Por meio desta, quanto mais se humilha, tanto mais se fortalece e resplandece. Ao final, se a mesma Tocha está tão virada que a mesma cera que queimava a mata, isto significa a Leviandade. Porém, se está direita, que é quando ilumina e pouco a pouco se consome, pode indicar um fundo moralizante, o que equivaleria a uma lição de verdadeira

\footnotetext{
${ }^{65} \mathrm{~A}$ palavra "emblema" advém do verbo grego emballo e significa "encaixar", indicando o mesmo que "encaixe", ou "lavor".

${ }^{66}$ Conservamos o uso das maiúsculas alegorizantes que foram exemplificadas por Hansen e cuja alusão remete às várias imagens que nos permitem interpretar mais de um significado em relação a um determinado símbolo.
} 
amizade e temperança, de bom comportamento do corpo ou mesmo de reta crença em Deus, mas essencialmente carrega consigo a dualidade amor/morte ao trazer um ensinamento sobre a efemeridade da vida.

Está presente em El Burlador de Sevilla a ideia de que a justiça dos homens pode ser considerada emblemática e passível de ser evocada pelo clima de instabilidade e desunião da nobreza ou mesmo pela atitude "discreta", que se revela ao manter as aparências em nome de um código de honra, destinado à preservação dos privilégios aristocráticos. Por isso, entre os homens já não mais se preserva a confiança. Essa insatisfação vivenciada pelo dramaturgo pode supor a necessidade de articulação de uma personagem que atue contra a expectativa da época. Tal personagem poderia expressar um poder de decisão, ao mostrar de forma objetiva, racional e incisiva como se configurava a ação política proposta por Platão em seu contexto. Assim, é dentro desse perfil que Dona Ana de Ulloa mobiliza a ação dramática, ao estabelecer uma espécie de intermediação entre um objetivo moralizador que o dramaturgo insere a partir do próprio enredo e uma proposta de comunicação de fundo edificante ao seu receptor, no caso, o público.

\subsection{Dona Ana e a justiça de Deus}

Sobre o objetivo moralizador, reiteramos que a autoridade paterna projetada na peça nos remete à perspectiva de uma instância simbólica. Podese dizer que a função dramática do pai de Dom Juan se prolonga através da personagem do pai de Dona Ana de Ulloa. Desse modo, antes do

enfrentamento entre Dom Juan e o Comendador, o pai de Dom Juan 
reconhece sua incapacidade para castigar o filho e afirma que o castigo compete a Deus.

Não devemos esquecer que Dom Gonzalo de Ulloa, representante da ordem religiosa de Calatrava, desdobra-se de maneira simbólica na peça. Primeiramente, ele se destaca como um dos privados do Rei de Castela, que sintetiza os valores positivos que se devem apreender no conjunto de sua atuação. Vejamos um exemplo em sua exaltação de alguns palácios e monumentos religiosos da cidade de Lisboa, perante o Rei de Castela:

\section{Don Gonzalo}

La mayor ciudad de España ${ }^{67}$.

(...)

Está de esa gran ciudad, poco más de media legua, Belén, convento del Santo, conocido por la piedra y por el León de guarda, donde los Reyes y reinas

Católicos y Cristianos tienen sus casas perpetuas ${ }^{68}$.

Um segundo aspecto do papel do Comendador corresponde à figura de um defensor da honra da Filha, carregando consigo uma moral que é encarnada pelo próprio pai. Provavelmente a beleza e a linhagem da Filha ${ }^{69}$ Ihe conferem os ingredientes para a representação de um ambiente de valores

\footnotetext{
${ }^{67}$ Verso 760 .

${ }^{68}$ Versos 786-793.

69"Por encima del 'decoro', el siglo XVII, por un fuerte sentido estético, cubrió la acción - esto es, la representó - con una tectónica pictórica en que la belleza y no la mera imitación es más importante que esa acción, por lo que lo psicológico queda mitigado u oscurecido. Este esteticismo responde a dos principios estéticos: la idea de que la Naturaleza por mucho cambiar es bella y el principio de ut pictura poesis." Cf. SÁNCHEZ ESCRIBANO, F. e PORQUERAS MAYO, A. Preceptiva Dramática Española: del renacimiento y el barroco. Madrid: Gredos, 1972, p.47-48. A partir desse comentário, reiteramos o papel emblemático que assume a personagem de Dona Ana, pois, segundo a preceptiva, toda ação da comédia espanhola é sempre uma "metáfora pictórica", alertando-se para o erro comum ao se dizer que os personagens da comédia espanhola carecem de psicologia ou personalidade próprias.
} 
tradicionais, evocado por Lisboa, no momento em que se sugere um instrumento de referência para que a ordem comprometida seja restaurada. Assim, a independência buscada por Ana de Ulloa visa à alteração de um estado tradicional de inércia da mulher e será a tentativa de se contornar o dilema encarnado por sua personagem:

Ana de Ulloa, simbólicamente representada en el papel traído por "a estafeta del viento", nos permite precisar que este plan de independencia amorosa implica la oposición a la autoridad paterna ("Mi padre infiel en secreto me ha casado sin poderme resistir") y la libertad para usar de su destino y de su amor según su deseo. Ana e Isabela representan y simbolizan en esta obra el tiempo de la elección de su pareja y su independencia para defender esa elección frente a la imposición paterna, reflejo de la autoridad del monarca. En este sentido hay que resaltar la homología entre Rey de Nápoles, que asume la ofensa de Isabela, y el Rey de Castilla, que es quien ha impuesto el matrimonio (que rehace sin tino poco después) de Ana de Ulloa con Don Juan (LÓPEZ-VÁSQUEZ, p. 88).

Ana de Ulloa, como portadora de uma vontade mais inclinada à possibilidade de amar aquele que lhe cabe, no caso o Marquês de la Mota, atua contra o próprio anseio do pai e do Rei, que já tinham decidido seu destino, e acaba por estabelecer o elo necessário com o transcendente. Dessa maneira, Dom Gonzalo, ao morrer lutando com o transgressor da ordem, Dom Juan, para salvaguardar a honra de sua filha, desdobra-se na representação legítima da figura de Pai, Senhor, Deus. O dramaturgo cria uma tensão vida e morte rumo ao futuro com reiteradas advertências.

La única aventura erótica que liga el mito del burlador con el del convidado de piedra, es justamente la experiencia fracasada con doña Ana. La figura de don Gonzalo, único muerto en toda la obra junto a don Juan, sirve de puente entre los dos mundos. La significación moral del castigo sobrenatural establece también la unidad entre los dos mitos y los encadena en una relación de causa y 
efecto preparada por el desprecio de la justicia divina que Don Juan ostenta a lo largo de su existencia (PEDRAZA JIMÉNEZ e RODRÍGUEZ CÁCERES, op. cit., p. 310).

Essa experiência fracassada nos chama a atenção, pois já que para Dom Juan o fato de seduzir uma mulher e deixá-la sem honra é causa de prazer, a cena de Dom Juan com Dona Ana obviamente serve de alerta para o ensinamento moral de que as donzelas devem se resguardar. Porém, com base na própria fundamentação lógica da trama, verifica-se que há também um desejo de se revigorar a ideia de que na vida "colhemos aquilo que plantamos". Com isso, a figura da Filha acaba por sugerir que as pessoas virtuosas, assim como seu pai, são capazes de evocar a justiça de Deus, como aquela que "tarda, mas não falha". Logo, a dor da Filha pela morte do pai sugere o fracasso da justiça dos homens, advindo assim uma descrença no ser humano, que se instaura a partir do caos social.

A presença do Convidado de Pedra, por sua vez, aponta para o ideal católico que carece ser revigorado, pois fica clara na peça uma necessidade de correção exemplar na conduta dos seres humanos, a qual deve ser sustentada pela fé, que não pode ser abalada pelos valores de cada um.

Podemos dizer que a Filha do Comendador também se insere na esfera do sujeito que toma uma decisão e não demonstra inconstância em relação àquilo em que acredita. Lembremo-nos que a Duquesa Isabela foi depreciada pelos homens devido à inconstância, considerada própria da mulher.

A reputação de Dona Ana talvez não seja abalada porque sua personagem representa a iniciativa do próprio ser humano, perdido em meio aos dilemas terrenos. Apesar disso, ela está em busca de ação para que as 
causas justas predominem e para que haja confiança nas decisões políticas, isso como reflexo do poder permanente de Deus. Por outras palavras, a reputação da Filha do Comendador fica intacta porque sua representação exemplifica um ideal católico de conduta, em que devem prevalecer a constância e a virtude, sempre com esperança na justiça divina.

\subsection{0 teatro dentro do teatro}

Segundo Orozco Días (1969), a interpretação do drama com base na perspectiva do teatro dentro do teatro é um recurso predominante entre os escritores do século XVII, relacionando-se a um sentimento de vida como teatro (vida fingida), ou mesmo a uma ideia de que por trás da cena está a realidade (vida real). Por isso, quando pensamos na presença da Filha em cena, aludimos ao papel que é representado pela personagem teatral cujas características envolvem uma espécie de duplo. Tal duplo se desmembra em vida real e vida fingida. Assim, enquanto o primeiro aspecto mais se relaciona a um tipo de questionamento dos valores inerentes à sociedade em questão, o segundo remonta à condição subalterna de Ana de Ulloa. Observemos o diálogo em que o Rei de Castela se refere ao Comendador como "mayor" de Calatrava. Nessa referência, verifica-se o quanto a ação dos cristãos tendia a difundir um temor dos árabes. São elementos da própria realidade que se inserem no discurso de decisão do Rei, ao oferecer a mão de Dona Ana ao Duque Octavio:

\section{Rey}

Comendador Mayor de Calatrava es Gonzalo de Ulloa, un caballero 
a quien el Moro por temor alaba, que siempre es el cobarde lisonjero; este tiene una hija, en quien bastaba en dote la virtud, que considero después de la beldad, que es maravilla y el sol de las estrellas de Sevilla. esta quiero que sea vuestra esposa ${ }^{70}$.

A Filha é manipulada pelas decisões do Rei e do Pai. Ela é a única das personagens femininas que, desde a nobreza até a esfera dos súditos, é referenciada por nome e sobrenome. Sua nomeação, portanto, é um elemento que a individualiza, o que lhe confere uma identidade que, assim como a de Dom Gonzalo, contém forte alusão à realidade do século XVII espanhol. Além disso, sabemos que a figura de seu pai, o Comendador, faz referência a uma tradicional ordem militar, a de Calatrava. A menção a tal ordem articula uma reafirmação da fé católica, em tempos de contestação à Reforma Protestante.

A Filha do Comendador é caprichosa e "discreta": sua figura, ao assumir características varonis, fortalece o pensamento crítico dos que viam um dilema social na inconstância dos homens da nobreza, responsáveis pela tomada de decisões $^{71}$. A personagem incorporou, na realidade, traços de uma aristocracia exemplar, que pudesse servir de modelo para um ideal de racionalidade política. Sendo assim, o universo ficcional do dramaturgo insere em Ana de Ulloa os elementos típicos de uma política "discreta", no intuito de se preservar uma reputação inabalável e a prudência como exemplum social.

No tocante ao aspecto fingido das ações da Filha na peça, as características que lhe são atribuídas indicam a construção de uma personagem que está disposta de maneira adversa àquilo que a expectativa

\footnotetext{
${ }^{70}$ Versos $1146-1154$

${ }^{71} \dot{E}$ interessante notar que, nessa personagem, a representação prima pela qualidade oposta, pois Dona Ana detém, como vimos, o poder de decisão.
} 
social poderia conceber. Em termos ficcionais, configura-se o quadro da donzela aristocrática (Filha de Comendador), caprichosa ("mi amor y mi voluntad"72), com pouca resistência aos desígnios masculinos ("no sé si podré

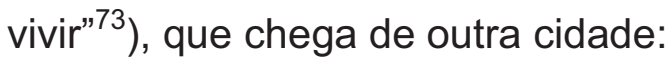

\section{Mota}

Doña Ana, mi prima,

Que es recién llegada aqui ${ }^{74}$.

Como já se viu, na descrição de seu pai, "Es Lisboa una octava maravilla:/De las entrañas de España ${ }^{75 "}$ e tanto mais. Tal cidade é representada como sendo o berço de uma tradição católica por excelência, "donde los Reyes y reinas/ Católicos y Cristianos/ tienen sus casas perpetuas" ${ }^{\prime 76}$. Portanto, em conformidade com essa tradição religiosa e com El Arte Nuevo de Hacer Comedias, não caberia à personagem feminina um caráter viril:

El gusto del auditorio, a pesar de todo el maquillaje teórico que otorgan las numerosas referencias cultas, es un principio revolucionario al tiempo que una premisa lógica comprendida por todos, a pesar de las hostilidades provenientes del sector más conservador de la crítica (LOPE DE VEGA, op. cit. p. 52).

\footnotetext{
${ }^{72}$ Verso 1367.

${ }^{73}$ Verso 1364.

${ }^{74}$ Versos $1300-1301$

${ }^{75}$ Versos $765-766$.

${ }^{76}$ Versos $791-793$
} 
Observamos que Dona Ana, mesmo quando assume uma atitude "viril" continua a se manter "discreta", não comprometendo a postura de Filha e guardiã da honra. Portanto, a personagem não transgride seu decoro.

\footnotetext{
Las damas no desdigan de su nombre,

Y si mudaren traje, sea de modo

Que pueda perdonarse, porque suele

El disfraz varonil agradar mucho ${ }^{77}$.
}

Para Lope de Vega (op. cit.), tal expectativa adversa contribui para a irreverência das personagens, ou mesmo para uma comicidade que muito agrada ao público exigente que caracterizava o teatro do século XVII. Isso porque a mulher já está inserida num mundo orientado por um código de honra, que faz com que uma ordem social, abalada efemeramente, deva ser reconstituída de qualquer maneira. Nesse perfil, podemos aplicar o termo que Hansen identificou como "emblema" e alertar o leitor sobre as imagens que poderão reincidir sobre a personagem. Isso para que sua interpretação não extrapole a atitude de Dona Ana, segundo uma visão extremista e anacrônica de feminismo, pois esse fenômeno não está relacionado com o contexto da expressão dramática do Século de Ouro:

(...) na hierarquia barroca determinada como "razão de Estado" a liberdade tem formulação paradoxal para nós, pós-iluministas, pois define-se como subordinação ao sistema dos privilégios; por isso, a posição social é deduzida da aparência e, da forma da representação (HANSSEN, 1996, p. 99).

O teatro dentro do teatro, na análise da personagem da Filha, constitui um recurso caracterizado por um jogo de habilidade do dramaturgo, através da

${ }^{77}$ Versos 280-283. 
técnica apurada e da consciência do efeito teatral, que nos levam a penetrar cada vez mais na essência da produção dramática. Assim, o aspecto verossímil confere certa espontaneidade à comédia. É interessante notar, ainda, que o duplo que sugerimos no início viabiliza também a relação autor/ator, ou seja, a identificação no âmbito da realidade e do ficcional, em que tanto o dramaturgo como o ator sentem o que se expressa.

Por fim, entenderemos o teatro como expressão direta da vida, mesmo na confusão entre plano real e ficção. No caso da presença de Dona Ana, observamos um sentido metafórico, que manifesta uma espécie de reafirmação do catolicismo. Sendo assim, o ator imita e não chega a ser, tal como Dona Ana, que imita o comportamento decisório masculino, sem por isso renunciar à sua feminilidade.

Além de pensar sobre a situação do ator ao representar, devemos identificar a personagem e ter consciência de que a vida humana é representação. No fim das contas, o ator é, em linhas gerais, espectador de si mesmo. Dona Ana de Ulloa se identifica como alguém que visa à realização de sua vontade através de um desejo incisivo e de uma constância demonstrada a cada passo. Ela é capaz de denunciar o fracasso das relações terrenas da nobreza, que carece de união e está subordinada às aparências em prol da preservação de seus privilégios. O aspecto moralizante de sua personagem busca reafirmar o ideal cristão da justiça, que norteia a lógica poética da peça.

\subsection{Uma "discreta" aleivosia ${ }^{78}$}

\footnotetext{
${ }^{78} \mathrm{O}$ heroísmo da Filha em uma situação contingente rendeu-nos uma comparação com as personagens de "Erec" (dilema) e da "Donzela Aleivosa" (ousadia), que se inserem no contexto da novela de cavalaria A Demanda do Santo Graal.
} 
O mito da mulher como símbolo do mal (MONGELLI, 1995) perdurou durante toda a Idade Média. Em termos culturais, na Península Ibérica esse período se caracterizou por uma religiosidade marcante. Com isso, a representação de uma mulher incisiva em suas atitudes, no século XVII, bem como do dilema masculino em relação à inconstância das decisões femininas, muito contribuiu para as reflexões sobre o papel das donzelas, já que

El personaje, en cuanto héroe dramático, es una persona puesta en pie sobre el drama por la conciencia del dramaturgo que, atento al vivir histórico de su tiempo y de su nación, refleja su problemática estructura, dramatizándola (RUIZ RAMÓN, op. cit., p. 152).

Podemos dizer que Dona Ana é figura daquela que trai sua própria consciência, já que sua atitude se revela simulada e ficcional, ainda que se explique por uma condição da mulher confinada, subserviente ao capricho daqueles que são de sua classe, mas pertencem ao sexo masculino.

Para refletir sobre as donzelas aristocráticas e entender o perfil de Dona Ana, recorremos a um texto medieval de inspiração religiosa, a narrativa d'A Demanda do Santo Graal. Trata-se de uma novela de relevância para a cultura ibérica, em especial para a literatura portuguesa. Nela se retratam as aventuras dos cavaleiros do Rei Artur em busca do cálice sagrado, que conteria o sangue recolhido por José de Arimatéia, quando Cristo estava crucificado. Essa busca - demanda - é repleta de simbolismo religioso.

Cumpre considerar ainda que o pensamento medieval é caracterizado pelo frequente recurso à alegoria. Isso faz com que o mundo seja visualizado como um símbolo, regido e estruturado por Deus. Não se pode esquecer que o pensamento religioso era amplamente predominante naquela sociedade. 
Dessa forma, as realidades materiais e as realidades imaginárias confundiamse, sendo passíveis de alegorização. O homem medieval concebia um dualismo de ideias, tais como Bem e Mal, que se relacionam ao alto e ao baixo, por exemplo. Esse dualismo típico do homem medieval é que fortalecia a concepção alegórica do mundo. O papel desempenhado pela mulher na literatura arturiana, em particular em A Demanda do Santo Graal, orienta nosso pensamento sobre a encruzilhada de influências, patente na construção das personagens femininas. Dona Ana estabelece uma comunicação com o público, em que o dualismo se revela pela mistura de simpatia e repulsão.

Diante do exposto sobre a alegoria medieval, lembre-se que oportunamente Hansen sugere que reflitamos sobre uma espécie de expressão alegórica de vida, observável também na construção das personagens dramáticas do século XVII. Seguindo essa sugestão é que procuraremos elucidar o que há de alegórico na figura de Filha do Comendador cujo papel se impulsiona por um poder de decisão. A expressão alegórica acaba por sustentar a mobilidade dramática dessa personagem feminina, em função da autoridade masculina retratada na peça. Uma abordagem inspirada, ou melhor, centrada, no âmbito de uma análise alegórica, faz-nos atentar à ideia de que a alegoria não pode ser concebida apenas como o resultado obtido por meio de uma tradução da obra na qual se insere a personagem ${ }^{79}$. A perspectiva alegórica será tida como um resultado das abstrações acerca da significativa presença da personagem feminina em questão.

Antes de tudo, observamos que a interpretação medieval da alegoria aponta para o inefável e nesse aspecto percebemos que "as coisas elevadas"

\footnotetext{
${ }^{79}$ Cf. LÓPEZ PINCIANO. Philosofía Antigua Poética, apud SHEPARD, op. cit., 1970, p.43: "ay muchas cosas en la Poética, y palabras ta(m)bién, $q(u e)$ parece $(n)$ mentirosas y no lo son, porque las cosas en lo literal falsas, muchas vezes se miran verdaderas en la alegoría..."(sic).
} 
da ordem poética estão para além de qualquer conceituação. Ademais, conforme atribui Hansen (1986), a expressão alegórica se refere ao modo em que a imaginação poética é construída, isso feito mediante as diferentes operações articuladas no cenário da ficção. Essas operações - assim dispostas - relêem textos históricos e acabam por inscrevê-los no paradigma teológico da Queda de Adão e Eva. Desse modo, ao postular o estatuto alegórico enquanto forma de expressão de Dona Ana de Ulloa e das personagens masculinas responsáveis por mobilizar sua ação dramática (a figura real, o Comendador, o Marquês de la Mota e Dom Juan), notamos que interpretar tal personagem feminina supõe a articulação do próprio discurso. Este é de cunho alegórico e acaba por postular uma transparência original, desvendada pelo público espectador graças à compreensão dos papéis masculino e feminino segundo um paradigma religioso, que a linguagem literária oculta. Em outras palavras, por essa linha de raciocínio, percebemos que os detentores do poder na peça são referenciados cenicamente em função do indivíduo do sexo masculino, que compõe uma classe dominante e cuja atitude comumente inclui uma postura de mando, no sentido de manter-se uma reputação. Tal postura se enquadra no perfil de comportamento socialmente "discreto" da realidade da época. Por assim dizer, cabe observar que os sentidos atribuídos à reputação e à honra se interpenetram. Segundo o dicionário Tesoro de la lengua castellana, de 1612, Covarrubias, no verbete "Honrado", "Honrado es el que está bien reputado, y merece que por su virtud y buenas partes se le haga honra y reverencia" (HANSEN, 1996, p. 94).

No entanto, a reação atribuída à personagem de Dona Ana de Ulloa desestabiliza a expectativa da expressão feminina de submissão, no contexto 
da sociedade retratada, e coloca à prova o referencial masculino no âmbito social, moral. Observamos, até, que o exercício do código de honra será guiado por um sentimento de necessidade de justiça poética perante a adversidade da condição da mulher. Assim, a visão de Hansen contribui para que entendamos melhor a expressão da autoridade masculina em El Burlador de Sevilla e o reflexo dessa representação no contexto de uma metáfora religiosa. Isso proposto no intuito de realimentar um modelo normal de subordinação, frente a um caso excepcional, o notável ato de decidir feminino, na hierarquia instalada na própria nobreza.

Nessa perspectiva, tudo indica que a significativa presença de Dona Ana de Ulloa está em consonância com o pensamento de Hansen e que a atitude desencadeada pela personagem possibilita um reconhecimento da realidade natural dos acontecimentos por intermédio do uso de alegorias. Isto é, do uso de uma forma de expressão amplamente empregada na alusão feita à sociedade medieval, em que se ambienta esta peça, sociedade cujo padrão alegórico tendia a mostrar que o visível é apenas um sinal de uma realidade mais aparente (CROMBIE, 1987). Tal pensamento nos permite estabelecer relação de analogia entre a personagem da Filha e a de seu pai, por um lado, e as figuras medievais de Erec e da donzela aleivosa, por outro (estes dois são, na verdade, personagens de A Demanda do Santo Graal). Essa relação, segundo Hansen (1986), é comum às novelas de cavalaria do ciclo do Graal, para cuja descrição remetemos ao estudo de Lênia Marcia Mongelli (op. cit.).

Ao fim e ao cabo, entendemos que o poder de decisão que é retratado na peça - e que se configura também por meio da representação de uma condição feminina da Filha do Comendador - tende a neutralizar uma ação 
decisiva que é típica da nobreza e, mais especificamente, típica das mãos dos homens. Em função disso, notamos que em A Demanda do Santo Graal, Erec se encontra desnorteado ao ter que decidir pela morte de sua irmã, a fim de cumprir o mandamento da honra. Tal atitude nos ajuda a entender a relevância da questão de honra na figura de Dom Gonzalo de Ulloa, pai de Dona Ana. Sua morte - alinhavada por Dom Juan - representa a consequência da decisão de um súdito do poder do monarca, que em nome de um código de honra articula a defesa de seu território de autoridade paterna, defesa destinada a culminar com a preservação de uma ordem efetiva e aparente. Sendo assim, cabe notarmos que a própria morte do Comendador reafirma um pressentimento e uma certeza de que a morte também é parte da realidade.

No fundo, sabemos que a honra será preservada, inclusive no limite que separa a vida da morte, em um mesmo status quo e em nome do Rei, alicerce que nutre as decisões. No entanto, a mulher dita "discreta" - como é o caso de Dona Ana -, ainda que sua atuação esteja também alicerçada no código de honra, expressa o ser humano de sexo "frágil", em condição hostil diante do poder de mando da nobreza masculina. Mas é esta nobreza que está sendo exaltada pela experimentação dramática, produzida como reflexo de um mundo que tende a valorizar as aparências, ao configurar a uma expectativa de ordem social.

Segundo Mongelli, no episódio "Erec mata sua irmã", Erec é um cavaleiro andante que possui uma passagem brevíssima por uma história anterior à própria novela. Tudo se inicia com dois cavaleiros, Galvam e Meraugis, que justam mortalmente ao serem reconhecidos por Erec. A partir de então, Meraugis passa a acompanhar Erec em busca de aventuras, até o 
momento em que este é abordado por uma donzela aleivosa ${ }^{80}$. Tal donzela cobrava um favor que teria feito, pois isso era comum à sociedade celta por possuir antigas e características tradições conservadas através dos tempos. Desse modo, em uma andança anterior, a donzela havia ajudado Erec a chegar a certa ilha. Como se sabe, um cavaleiro medieval não mente de propósito. Assim, a aventura do ilustre rapaz tende a demonstrar que a mentira proposital faz parte do ser humano. Erec realiza o desejo da donzela e ambos os cavaleiros a acompanham até chegarem casualmente ao castelo do pai de Erec.

Assim, o fidalgo medieval retorna ao seu castelo com a ajuda da donzela traidora, que Ihe cobra pelo favor. Ela queria a cabeça da irmã de Erec; ele argumenta que sua irmã é bonita, mas a donzela pouco se importa. Logo se arma um dilema para Erec, que se constituirá no centro de interesse da história: desonrar-se por não cumprir sua palavra, ou cometer uma violência brutal e infamante com sua irmã. Com isso o herói perde a noção das proporções, pois dizer uma mentira seria tão grave como degolar a própria irmã.

Por fim, Erec mata a irmã, e a donzela prontamente cavalga feliz com seu troféu. Então um raio atinge a donzela, matando-a juntamente com seu cavalo. Entretanto, a cabeça da aleivosa fica intacta.

No que concerne à valorização de uma supremacia cujo fundo intencional motiva a construção de uma personagem historicamente em estado

\footnotetext{
${ }^{80}$ Para donzela, as acepções de "virgem", "mulher solteira", "mulher que quer passar por virgem sem o ser" encontram-se no dicionário Michaelis e no Glossário de Nunes, na página 540. Segundo o Aurélio (1975), a mesma lexia era empregada primitivamente, além das acepções anteriores, também como "mulher moça nobre", hoje em desuso. Além disso, encontramos sua variante gráfica doncela, do latim vulgar domnicilla, diminutivo de domna, ou seja, "senhora".
} 
de submissão, ou melhor, em uma clássica situação de dependência ao poder masculino, pode-se identificar aqui um traço peculiar da figura de Ana de Ulloa. Traço que a destaca e que permite a alusão a Dom Juan Tenorio como concretização daquelas personagens que se individualizam e conquistam um espaço nas mentalidades dos dramaturgos mais contemporâneos ${ }^{81}$. De acordo com o exemplo de A Demanda do Santo Graal, Dom Juan faz lembrar Erec, ilustre cavaleiro andante. Ambos acreditam que não há limite para o gozo pleno do instante, buscando superar os obstáculos apresentados pelo acaso (no sentido etimológico de "aventura"). Isso representa uma superação constante. No meio da aventura, mesmo diante do inesperado, surge a figura da donzela aleivosa na perspectiva daquela que ilude a própria consciência, não apenas a individual mas também a de toda uma coletividade regida por um único código: a honra. Sabemos que a aleivosia constitui um comportamento e um sentimento traiçoeiro do próprio consciente, evocando na personagem em questão uma espécie de frustração diante das decisões que são prerrogativas dos homens.

Podemos dizer que a donzela aleivosa é uma personagem necessária no episódio apontado por Mongelli. Ela se insere no caminho de Erec para revelar aquilo que era somente do cavaleiro. Em termos alegóricos, isso alude ao que Erec fazia em A Demanda do Santo Graal.

Dona Ana também parece mentir de propósito. Subordinada às decisões masculinas, revela seu poder de decisão, que é incisivo naquilo que almeja e

\footnotetext{
${ }^{81}$ Mencionamos algumas alusões à Filha do Comendador encontradas entre contemporâneos de El Burlador de Sevilla, ou seja, a mulher que redime os malfeitos de seu sedutor — em Don Juan Tenorio, de José Zorrilla; a mulher solicitada como esposa e esquecida então — em Don Juan o Convidado de Pedra, de Molière; e, ainda: a mulher tratada por sua engenhosidade e cumplicidade com outra vítima em situação igual, isso feito em função da condição subalterna de mulher seduzida que lhe é atribuída a partir de um ponto fraco de seu sedutor - Don Giovanni ou O Dissoluto Absolvido, de José Saramago.
} 
surpreende pela constância. Em outras palavras, a personagem da Filha do Comendador parece estar alinhada entre os homens que são, na verdade, os articuladores do poder político. Sendo correta e responsável, ela não poderia ser norteada por valores instáveis ou mesmo por um relativismo na diversidade das opiniões. Com base em uma referência clássica do procedimento político nas mãos masculinas, vislumbramos a ação feminina também espelhada no princípio de conservação da honra. Em nome de uma reputação que não poderia ser abalada quanto às aparências, em prol da manutenção dos privilégios da aristocracia, Dona Ana se mostra dissimulada entre os nobres da peça. Sua dissimulação assegura aquilo que consideramos como uma "política de ajustes", por meio da qual o Rei detinha o poder de decisão e uma hierarquia (Rei-Comendador/Pai-Filha), dentro da própria nobreza, fazia com que as decisões do soberano fossem levadas a cabo. 


\section{CONSIDERAÇÕES FINAIS}

¿Qué es la vida? Un frenesí
¿Qué es la vida? Una ilusión,
una sombra, una ficción,
y el mayor bien es pequeño;
que toda la vida es sueño,
y los sueños, sueños son.

CALDERÓN DE LA BARCA

Ao longo de nossa leitura, buscamos esclarecer os motivos que favoreceram a construção e a formação de um perfil de se agir discretamente, como parte de uma atitude "caprichosa" da Filha do Comendador ${ }^{82}$. Essa personagem feminina promove uma resistência oriunda de uma situação conflituosa, instaurada pela autoridade do pai e do Rei, bem como pelos demais fatores de uma política cuja representação inspira sua figura, necessária à comédia. Também desenvolvemos os motivos que levaram ao fracasso da personagem que se conserva na subalterna condição feminina (representada pela Duquesa Isabela, embora ela seja "igual", pertencente à aristocracia). Como se viu, Ana de Ulloa adere à discrição. Pelo exposto no capítulo inicial, verifica-se que ela se aproxima dos mecanismos da política vigente, servindo para ilustrar o cenário social de El Burlador de Sevilla. De certo modo, Ana de Ulloa transgride uma condição feminina de subjugada, manifestando seu poder de decisão e tratando a autoridade masculina com certa soberania. Dotada de juízo, ela age com discrição e nos revela um duplo, a partir de seu desejo, este entendido como cobiça.

Colocamo-nos, assim, diante desse duplo, cuja essência nos permite interpretar os dois mundos que se complementam. Um deles busca denunciar

\footnotetext{
${ }^{82}$ Sobre o perfil de algumas personagens femininas no século XVII, aludimos ao comentário de RICO, Francisco. Historia y crítica de la literatura española. Suplementos (I y II). Barcelona: Crítica, 1991, p.471.
} 
uma nobreza de ação inconstante, cuja expressão se manifesta por meio do uso do poder de decisão. Isso é levado a cabo, também, por meio de Dona Ana de Ulloa, a fim de se preservar um status quo e garantir a manutenção de uma ordem social e de uma gama de privilégios, a qualquer preço. Por outro lado, aponta-se para o mundo de uma justiça divina, evocada por atitudes políticas, inclusive pela ordem militar de Calatrava, cujo representante é Dom Gonzalo. Desse modo, o papel do pai, militante de Calatrava, acaba por revigorar e dar consistência a uma poética de moralidade, que atua com a finalidade de fundamentar de maneira lógica uma espécie de justiça poética na trama. Tais fatores são capazes de guiar a construção da personagem da Filha do Comendador, contribuindo para que ela venha a assumir um traço peculiar aos homens da nobreza: o poder de tomar uma decisão. Trata-se de uma audaciosa empreitada do dramaturgo, se levamos em conta a representação habitual da mulher, que tanto no lar como na sociedade, parecia configurar-se como submissa aos caprichos masculinos. Portanto, estamos diante da representação do "discreto", o que serve de alerta sobre um aspecto subjugado da expressão feminina no século XVII, embora tal expressão seja articulada na peça de maneira decorosa pela Filha do Comendador.

A perspectiva do teatro dentro do teatro, naquilo que compete à presença de Dona Ana na peça, chama nossa atenção para uma representação da justiça terrena que, em El Burlador de Sevilla, se revela falha, subjetiva e favorecedora de privilégios individuais (como, aliás, vem se conservando ao longo da história da humanidade em quase todas as sociedades). Assim se alimenta a construção de uma personagem feminina, sustentada por uma atitude "discreta". Ao cobiçar incisivamente e preservar sua 
condição de filha de um comendador, mantém a lucidez entre os valores almejados e o status quo que a representa. Essa figura denuncia o fracasso das relações terrenas da nobreza em função de uma imparcialidade no ato de tomar decisões. Nobreza esta que se subordinada às aparências, em prol da preservação de seus privilégios no terreno do mundo concreto, não ficcional.

O aspecto moralizante da peça reafirma, ainda, o ideal cristão de justiça, configurando a lógica de uma poética de moralidade, típica do século XVII. Assim, Ana de Ulloa traz consigo a imagem do "tal pai tal filha", retomando de maneira expressiva elementos do ideal cristão, através da presença da ordem religiosa de Calatrava e da crítica ao sistema político, marcado por seres humanos inquietos e individualistas. Tais elementos são capazes de revelarnos os valores que deveriam ser comuns a todos os seres humanos, tais como a prudência, a lealdade ou a temperança, virtudes que orientam um comportamento exemplar e capaz de desencadear uma lógica sobre os fundamentos cristãos como premissa da ordem social. Esses valores acabam por enfatizar a dualidade amor/morte, ao alertarem para a efemeridade da vida e de seus prazeres, tanto no plano ficcional quanto no real. Os aspectos políticos também se interpenetram no campo de uma moralidade cristã, o que se constitui como um ensinamento.

Notamos que as representações da autoridade estabelecem um vínculo com o público, pois este se vê posto diante da necessidade de reagir às circunstâncias desfavoráveis. Isto, muitas vezes, acarretará um comportamento "discreto", tanto na esfera da representação ficcional quanto na da realidade.

Assim como Dom Juan, Dona Ana de Ulloa se situa à margem de uma sociedade regida por um sistema de normas que acabam por sugerir a 
limitação da esfera individual, ao inseri-la em um mundo historicamente concreto e repleto de valores condicionantes de suas atitudes perante certas adversidades que carecem de superação. Isso caracteriza o surgimento de uma expressão de identidade, necessária ao indivíduo.

Por último, é interessante notar como a perenidade dessa personagem feminina - única mulher na peça que é tratada por nome e sobrenome - se evidencia nas recriações de El Burlador de Sevilla por dramaturgos como José Zorrilla e Molière, entre outros, o que demonstra que, em sua essência, há um conflito que perdura ao longo dos tempos. A reflexão sobre o papel de Dona Ana de Ulloa em sua atitude "discreta" se encaixa em qualquer sociedade e pode aplicar-se a qualquer época. 


\section{REFERÊNCIAS BIBLIOGRÁFICAS}

ARELLANO, Ignacio. Historia del Teatro Español del Siglo XVII. Madrid: Cátedra, 1995.

ARISTÓTELES. Poética; Organon; Política constituição de Atenas. In: Os Pensadores. Tradução de: Baby Abrão. São Paulo: Nova Cultural, 2000.

ARMESTO, Victor Said. La Leyenda de Don Juan: orígenes poéticos de El burlador de Sevilla y Convidado de Piedra. Buenos Aires: Espasa-Calpe, 1946.

AVILLÉS, VILLAS \& CREMADES. Historia de España: la crisis del siglo XVII bajo los últimos Áustrias (1598-1700). Madrid: Gredos, 1988.

BERTHOLD, Margot. História Mundial do Teatro. São Paulo: Perspectiva, 2004.

BLANCO AGUINAGA, Carlos; RODRÍGUEZ PUÉRTOLAS, Julio; ZAVALA, Iris. Historia Social de la Literatura Española (en lengua castellana). Madrid: Akal, 2000. Tomo I.

BLOCH, R. H. Misoginia Medieval e a Invenção do Amor Romântico Ocidental. Tradução de Claudia Moraes. São Paulo: 34,1995.

CÂNDIDO, Antonio (org.). A Personagem de Ficção. São Paulo: Perspectiva, 2004.

CASTIGLIONE, Baltasar. El Cortesano. Tradução de Juan Boscán, 1528. Madrid: Espasa-Calpe, 2009.

CARLSON, Marvin. Teorias do Teatro: estudo histórico-crítico, dos gregos à atualidade. São Paulo: Edunesp, 1997.

CHACÓN, Francisco (ed.). Familia y Sociedad en el Mediterráneo Occidental. Siglos XV-XIX. Murcia: Universidad de Murcia, 1987.

CORTESÃO, Jaime. A política de sigilo nos descobrimentos. In: Coleção Henriquina. Lisboa: Comissão executiva das comemorações do quinto centenário da morte do infante D. Henrique, 1960.

CROMBIE, Alistair C. Historia de la Ciencia de San Agustín a Galileo. Siglos VXIII. Traducão de José Bernia. Madrid: Alianza Universitaria, 1987. 2v. (Original publicado em 1959).

CUNHA, Antônio Geraldo da. Dicionário Etimológico da Língua Portuguesa. Rio de Janeiro: Nova Fronteira, 1986.

DIEZ BORQUE, José María. Sociología de la Comedia Española del Siglo XVII. Madrid: Cátedra, 1976. 
DOLFI, Laura. El Burlador Burlado: Don Juan en el teatro de Tirso de Molina. Alicante: Biblioteca Virtual Miguel de Cervantes, 2006. Disponível em $<$ http://www.cervantesvirtual.com/FichaObra.html?Ref=19544>. Acesso em: $15 / 02 / 2010$.

DUBOIS, M. Mito e Realidade. São Paulo: Perspectiva, 1972.

DURÁN, Manuel; ECHEVARRÍA, Roberto González. Luz y Oscuridad: la estructura simbólica de 'El Burlador de Sevilla'. Madrid: Castalia, 1983, p. 201209.

EGIDO, Aurora. Historia y Crítica de la Literatura Española. Barcelona: Crítica, 1992.

EURÍPIDES. Medéia / As Bacantes. Tradução de Miroel Silveira, Junia Silveira Gonçalves e Eudoro de Souza. São Paulo: Abril Cultural, 1976.

FERNÁNDEZ ÁlVAREZ, Manuel. La Sociedad Española en el Siglo de Oro. Madrid: Nacional, 1984

Fábulas de Identidade. São Paulo: Nova Alexandria, 2000.

FERREIRA, Aurélio Buarque de Holanda. Novo Dicionário da Língua Portuguesa. Rio de Janeiro: Nova Fronteira, 1975.

GARCÍA LORENZO, Luciano; VEGA GARCÍA-LUENGOS, German [et. al.]. Diccionario de la Comedia del Siglo de Oro. Madrid: Castalia, 2002.

GONZÁLEZ-GONZÁLEZ, Luis Miguel. La Mujer en el Teatro del Siglo de Oro Español. In: Revista de Estudios Teatrales, Madrid, n. 6-7, 1994-1995, p. 41-70.

GONZÁLEZ, Mario Miguel. Don Juan: burlador, seducido y seductor. In: OLIVEIRA, Ester Vieira de Abreu e CASER, Maria Mirtis (orgs.). Universo Hispánico: Lengua. Literatura. Cultura. Vitória: UFES/APEES, 2001, p. 212214.

. Introdução. In: MOLINA, Tirso de (atribuída a). O Burlador de Sevilha e o Convidado de Pedra. Tradução de Alex Cojorian. Brasília: Círculo de Brasília, 2004.

HANSEN, João Adolfo. Alegoria: construção e interpretação da metáfora. São Paulo: Atual, 1986.

- Discreto/Vulgar: modelos culturais nas práticas da representação barroca. In: Estudos Portugueses e Africanos, Campinas, v. 17, Jan/Jun, 1991, p. 29-57.

Notas sobre el Barroco. In: Revista de Filología, Universidad de Canarias, v. 22, enero 2004, p. 11-131. 
Discreto. In: NOVAES, Adauto (org.) Libertinos e Libertários. São Paulo: MINC/FUNARTE/Companhia das Letras, 1996, p. 77-102.

KOTHE, Flávio R. A Alegoria. São Paulo: Ática, 1986.

LAUSBERG, Heinrich. Elementos de Retórica Literária. Lisboa: Gulbenkian, 1982.

LOPE DE VEGA, F. El Arte Nuevo de Hacer Comedias. Madrid: Cátedra, 2006.

MAEZTU, Ramiro de. Don Juan o el Poder. In: MAEZTU, Ramiro de (org.). Colección Austral: Don Quijote, Don Juan y La Celestina. Madrid: EspasaCalpe, 1981. p. 71-106.

MARAÑÓN, Gregorio. Don Juan: ensayos sobre el origen de su leyenda. Buenos Aires: Espasa-Calpe, 1946.

MÁRQUEZ VILLANUEVA, Francisco. Orígenes y Elaboración de 'El Burlador de Sevilla'. Salamanca: Universidad de Salamanca, 1996.

MATTOSO, Antônio G. História de Portugal. Lisboa: Sá Costa, 1939.

MEGALE, Heitor. O Jogo dos Anteparos - 'A Demanda do Santo Graal': a estrutura ideológica e a construção da narrativa. São Paulo: T. A. Queiroz, 1992.

MENÉNDEZ PIDAL, Ramón. Historia de la Cultura Española: el siglo del Quijote (1580-1680). Madrid: Espasa Calpe, 1996.

MICHAELIS. Moderno Dicionário da Língua Portuguesa. São Paulo: Melhoramentos, 2002.

MOLIĖRE. Don Juan. O Convidado de Pedra. Porto Alegre: L\&MP, 1997.

MOLINA, Tirso de. Cigarrales de Toledo. Madrid: Espasa-Calpe, 1968.

(atribuída a). El Burlador de Sevilla. Edição de Alfredo Rodríguez López-Vázquez. Madrid: Cátedra, 2005.

MONGELLI, Lênia M. Por Quem Peregrinam os Cavaleiros de Artur. São Paulo: İbis, 1995.

NUNES, Irene F. A Demanda do Santo Graal. Lisboa: Imprensa Nacional/Casa da Moeda, 1995.

OROZCO DÍAZ, Emilio. El Teatro y la Teatralidad del Barroco. Barcelona: Editorial Planeta, 1969.

ORTEGA Y GASSET, José. Estudios sobre el Amor. Madrid: Alianza, 1984. 
PARKER, Alexandre A. La Filosofía del Amor en la Literatura Española 14801680. Tradução de Javier Franco. Madrid: Cátedra, 1986.

PEDRAZA JIMÉNEZ, Felipe Blas. Sexo, Poder y Justicia en la Comedia Española. Vigo: Editorial Academia del Hispanismo, 2007.

PEDRAZA JIMÉNEZ, Felipe Blas; RODRÍGUEZ CÁCERES, Milagros. Manual de Literatura Española: barroco - teatro. Pamplona: Cénlit, 1995.

PORQUERAS MAYO, Alberto. El Problema de la Verdad Poética en el Siglo de Oro. Madrid: Ateneo, 1961.

RÉGNIER-BOHLER, Danielle. Vozes Literárias, Vozes Místicas. In: Duby, G; Perrot, M. História das Mulheres no Ocidente: a Idade Média. Porto: Afrontamento, 1992.

RIBEIRO, Lilian dos Santos S. Don Juan e a Construção de um Mito em 'El Burlador de Sevilla'. Dissertação de Mestrado. São Paulo: USP/Faculdade de Filosofia, Letras e Ciências Humanas, 2007.

RIBEIRO, Renato J. (org.). A Sedução e suas Máscaras: ensaios sobre Don Juan. São Paulo: Companhia das Letras, 1988.

RICO, Francisco (dir.). Historia y Crítica de la Literatura Española. Suplementos (I y II). Barcelona: Crítica, 1991.

RICO, F. (org.). Historia y Crítica de la Literatura Española: Siglos de Oro Barroco - primer suplemento. Barcelona: Grijalbo, 1980/1992. v. 03.

RODRIGUES, Antonio M. De Don Juan e Donjuanismo. In: RIBEIRO, Renato Janine (org.). A Sedução e suas Máscaras: ensaios sobre Don Juan. São Paulo: Companhia das Letras, 1988, p. 53-70.

. O Mito de Don Juan e Outros Ensaios. Lisboa: Edições Ró, 1981.

RODRÍGUEZ MANPASO, M. J., HIDALGO BLANCO, E.; WAGNER, C.G. (eds.). Roles Sexuales: las mujeres en la historia y la cultura. Madrid: Ediciones Clásicas, 1994.

ROSENFELD, Anatol. O Teatro Épico. São Paulo: Perspectiva, 2004.

ROUSSET, Jean. Don Juan ou as Metamorfoses de uma Estrutura. In: Rousset, Jean (org.). O Mito de Don Juan. Lisboa: Vega Universidade, [s.d.], p.27-39.

RUIZ RAMÓN, Francisco. Historia del Teatro Español (Desde sus orígenes hasta 1900). Madrid: Alianza Editorial, 1971.

Paradigmas del Teatro Clásico Español. Madrid: Cátedra, 1997. 
SÁNCHEZ ESCRIBANO, Federico. y PORQUERAS MAYO, Alberto. Preceptiva Dramática Española: del renacimiento y el barroco. Madrid: Gredos, 1972.

SANTOS, Laymert Garcia dos. Don Juan e o nome da sedução. In: RIBEIRO, Renato Janine (org.). A Sedução e suas Máscaras: ensaios sobre Don Juan. São Paulo: Companhia das Letras, 1988, p. 23-37.

SHEPARD, Sanford. El Pinciano y las Teorías Literarias del Siglo de Oro. Madrid: Gredos, 1970.

SARAMAGO, José. Don Giovanni ou O Dissoluto Absolvido. São Paulo: Companhia das Letras, 2005.

VALBUENA PRAT, Angel. Historia de la Literatura Española. Barcelona: Juventud, 1951.

VAREY, John E. Cosmovisión y Escenografía. Madrid: Castalia, 1987.

VITSE, Marc. Las Burlas de Don Juan: viejos mitos y mito nuevo. In: RUIZ RAMÓN, Francisco; OLIVA, César (orgs.). El Mito en el Teatro Clásico Español. Madrid: Taurus, 1988.

WATT, Ian P. Mitos do Individualismo Moderno: Fausto, Dom Quixote, Dom Juan, Robinson Crusoe. Tradução de Mário Pontes. Rio de Janeiro: Jorge Zahar, 1997.

OLIVA, César (org.). El Mito en el Teatro Clásico Español. Madrid: Taurus, 1988.

WEINER, Jack. En Busca de la Justicia Social: estudios sobre el teatro español del Siglo de Oro. Potomac (Maryland): Scripta Humanística, 1984.

WILSON, Edward M. Siglo de Oro: teatro (1492-1700). Barcelona: Ariel, 1992.

ZORRILLA, José. Don Juan Tenorio. Madrid: Alianza Editorial, 2006. 